\title{
Streamflow From the
}

\section{United States Into the}

\section{Atlantic Ocean Durirg}

$1931-60$

GE OLOGICAL SURVEY WATER-S UPP LY PAPER 1899-1

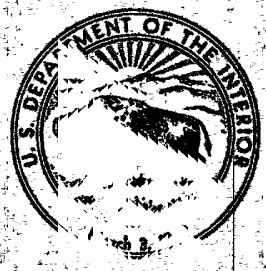

OKLAFOMA CITY, OKLA.

RECEIVED

APR 241970

$45 \mathrm{G} S$
WATER RESOURCES DIVISION 


\section{Streamflow From the}

United States Into the

Atlantic Ocean During

\section{$1931-60$}

By CONRAD D. BUE

CONTRIBUTIONS TO THE HYDROLOGY OF THE UNITEE STATES

GEOLOGICAL SURVEY WATER-SUPPLY PAPER 1899-I

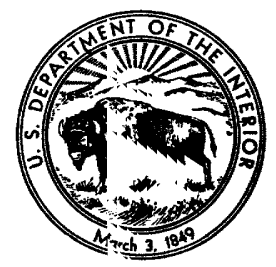


UNITED STATES DEPARTMENT OF THE INTERIOR

WALTER J. HICKEL, Secretary

\author{
GEOLOGICAL SURVEY
}

William T. Pecora, Director 


\section{CONTENTS}

\begin{tabular}{|c|c|}
\hline tract.. & $\begin{array}{r}\text { Page } \\
\text { I1 }\end{array}$ \\
\hline 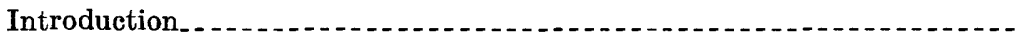 & $\mathbf{1}$ \\
\hline Purpose and scope... & $\mathbf{1}$ \\
\hline Drainage areas............. & 3 \\
\hline coastline. & 3 \\
\hline ating discharge from ungaged areas & 6 \\
\hline Period 1951-60 & 6 \\
\hline Period 1931-50 & 6 \\
\hline justment for major diversions. & 11 \\
\hline Municipal use_..................... & 11 \\
\hline Chesapeake and Delaware Canal & 14 \\
\hline Diversion from the Santee River to the Cooper River & 15 \\
\hline eamflow & 16 \\
\hline Summary of streamflow into the Atlantic Ocean & 16 \\
\hline Discharge of the Hudson River at mouth, 1890-1960 & 20 \\
\hline Discharge of the Charles River at mouth, 1920-60 & 29 \\
\hline Mean monthly discharge of the Penobscot and James Rivers, 1951-60_ & 29 \\
\hline Discharge of principal rivers, 1951-60 and 1931-60 & 30 \\
\hline Comparison between different periods & 32 \\
\hline ences_......... & 35 \\
\hline
\end{tabular}

\section{ILLUSTRATIONS}

Figures 1-3. Graphs showing:

1. Use of water by New York City ................

2. Pattern of streamflow into the Atlantic Ocean, 1931-60.

3. Mean monthly discharge of Penobscot and James Rivers, 1951-60 


\section{TABLES}

TABLE

1. Use of water by New York City

Page

2. Components of discharge from reach 28

3. Streamflow into the Atlantic Ocean by segments

4-13. Discharge from reaches-

4. 1-4, segment 1

5. 5-10, segment 2

6. 11-16, segment 3

7. 17-20, segment 4

8. 21-23, segment 5

9. 24 and 25 , segment 6 .

10. 26 and 27 , segment 7

11. 28-30, segment 8...

12. 31 and 32 , segment 9

13. 33 and 34 , segment 10 .

14. Annual discharge of Hudson River at mouth, 1890-1950_..-

15. Spill from Croton Reservoir.........

16. Annual discharge of the Charles River at mouth and sewage waste into Boston Harbor, 1920-60.

17. Mean monthly discharge of the Penobscot and James Rivers 1951-60

18. Discharge of principal rivers, 1951-60 and 1931-60.......

19. Comparison between means for 10 - and 30 -year periods and period of record at selected gaging stations on principal rivers. 


\title{
CONTRIBUTIONS TO THE HYDROLOGY OF THE UNITED STATES
}

\section{STREAMFLOW FROM THE UNITED STATES INT) THE ATLANTIC OGEAN DURING 1931-60}

\author{
By Conrad D. Bue
}

\section{ABSTRACT}

Streamflow from the United States into the Atlantic Ocean, between the international stream St. Croix River, inclusive, and Cape Sable, Fla., averaced about 355,000 cfs (cubic feet per second) during the 30-year period 1931-60, $0^{*}$ roughly 20 percent of the water that, on the average flows out of the contermino's United States. The area drained by streams flowing into the Atlantic Ocean is about 288,000 square miles, including the Canadian part of the St. Croix and Connecticut River basins, or a little less than 10 percent of the area of the conterminons United States. Hence, the average streamflow into the Atlantic Ocean, in terms of cubic feet per second per square mile, is about twice the national average of the flow that leaves the conterminous United States. Flow from about three-fourths of the area draining into the Atlantic Ocean is gaged at streamflow measuring stations of the U.S. Geological Survey. The remaining one-fourth of the drairage area consists mostly of low-lying coastal areas from which the flow was extimated, largely on the basis of nearby gaging stations.

Streamflow, in terms of cubic feet per second per square mile, decreases rather progressively from north to south. It averages nearly 2 cfs along the Maine coast, about 1 cfs along the North Carolina coast, and about 0.9 cfs along the Florida coast.

\section{INTRODUCTION}

\section{PURPOSE AND SCOPE}

The original purpose of this study was to furnish data on str?amflow into the Atlantic Ocean as requested by the Woods Hole Oceanc oraphic Institution. The data consisted of the following: Discharge by years from specified segments of coastline for a 10-year period (the period not specified), discharge of the Charles River at mouth for the period 1920-60, discharge of the Hudson River at mouth for the period 1890-1960, and mean monthly discharge of the Penobscot and James Rivers at mouth for a 10-year period (the period not specified). The 10-year period 1951-60 was selected, partly because more strıamflow 
records were available for that period than for any earlier period and partly because it was presumed that data for a recent perind would be more useful to the institution than those for an earlier period.

The coastline between the Canadian border and Cape Sable, Fla., was divided into 10 segments, as proposed by Dr. K. O. Fmery of the Woods Hole Oceanographic Institution. For convenience, the segments of coastline were divided into reaches, some reaches consisting of the mouths of individual rivers or bays. The segments range, in size of contributing drainage area, from 10,808 square miles to 79,260 square miles. The total contributing drainage area is 288,339 square miles, of which about three-fourths is gaged. Flow from the remaining onefourth, which consists mostly of coastal areas, was estimated on the basis of streamflow records from nearby gaging stations.

Figures of discharge into the ocean between Cape Kennedy and Cape Sable were furnished by the Tallahassee office of the U.S. Geological Survey. Much of the area along the coast from Crpe Kennedy to St. Lucie Canal contains well-developed canal systems constructed by drainage districts. The major drainage canals were gaged during the entire 10-year period; flow in other canals having shorter records was estimated from the short-term records. From St. Lucie Canal southward to Cape Sable about 85 percent of the drainage to the ocean was gaged as of 1965 .

After the original 10-year study was completed, the study was extended back to 1931 so as to coincide with the standard reference period 1931-60.

For the purpose of determining flow into the ocean, water wasted from cities along the coast was added to the observed streamflow where the waste was large enough to be of some significance. Cities for which the wastes were thus accounted are Boston, New York, Philadelphia, Baltimore, and Washington, D.C. Where figures of actual waste were not available, it was assumed that the waste was equivalent to the water consumption of the city. Streamflow records used herein are, with certain exceptions, the observed discharges as measured at gaging stations and do not include water diverted upstream from the gaging stations for municipal use by downstream cities. Hence, where these diversions are of significant size, it is appropriate that they be accounted for by adding the waste water to obtain the total inflow into the ocean.

For the purpose of estimating ungaged inflow to the Hudson River below Mechanicville, the 378 square miles of drainage ares of the Croton River above the Croton Dam was withdrawn as being noncontributing, because all the water of the Croton River is diverted at the dam for municipal use by New York City, except for occasional spill at the 
dam. The spill, measured at a gaging station just below the dam, was added to the fllow of the Hudson River. The water direrted to New York City is assumed to be wasted into the bay beyond the mouth of the Hudson River and was included in the outflow from reach 18. Figures of drainage area of the Hudson River, however, as well as those for reach 18, include the Croton River basin.

\section{DRAINAGE AREAS}

Streamflow reports of the U.S. Geological Survey give drainage areas at all gaging stations used in this study. Gaging stations are, however, almost invariably located some distance above the mouth of the stream and above tidewater, so that the lower reaches of rivers tributary to the ocean are ungaged, and many small coastal $k$ asins are wholly ungaged. For areas of ungaged drainages, the following various reports were consulted: Carter (1959), Maine State Water Storage Commission (1910 and 1913), Vermeule (1894), Virginia Department of Conservation and Economic Development (1960), and Walker (1962).

For the other coastal States, supplementary drainage area data were obtained from the district offices of the Geological Survey, mostly in mimeographed, unpublished form. Some supplemental drainage area data were also available in the Corps of Engineers" "308" reportsreports prepared under the provisions of House Document No. 308, 69 th Congress, first session.

The areas of many small basins, or subbasins, were meast red with a planimeter. As the maps used were small scale, the areas are subject to a fairly large percentage error, but as these areas constitute only a very small part of the total area, the overall error from this source is probably insignificant. In some basins, where the total drainage area had already been determined-by the Corps of Engineers on another agency-it was possible to adjust the planimetered areas so that the sum of all the subareas within the basin agreed with the total. Wherever possible, such adjustments were made to the planimetered areas to avoid inconsistencies with figures already published.

\section{DIVISIONS OF COASTLINE}

\section{SEGMENT 1}

St. Croix River to Penobseot Bay, inclusive

Reach 1: St. Croix River to the East Machias River, inclusive. Reach 2: Machias River to Pleasant Bay, exclusive of the Narraguagus River.

Reach 3. Narraguagus River to but excluding Penobscot Bay. 
Reach 4: Penobscot Bay, which includes the Penobsco ${ }^{+}$River and contributing areas on the right and left banks of the bay.

\section{SEGMENT 2}

From Penobseot Bay to Orleans, Mass.

Reach 5: From Penobscot Bay to and including the outer exit of the Kennebec and Androscoggin Rivers.

Reach 6: From the Androscoggin River to and including the Saco River.

Reach 7: From the Saco River to and including the Piscataqua River.

Reach 8: From the Piscataqua River to Cape Ann, Mass.

Reach 9: Massachusetts Bay, extending from Cape Ann to the $42 \mathrm{~d}$ parallel.

Reach 10: From the 42d parallel to Orleans, Mass. This reach consists mainly of Cape Cod Bay.

\section{SEGMENT 3}

From Orleans, Mass., to the Connecticut-New York State line

Reach 11: From Orleans to but exclusive of the Taunton River.

Reach 12: Narraganset Bay, including the Taunton River.

Reach 13: From Narraganset Bay to the Rhode Island-Connecticut State line.

Reach 14: From the Rhode Island-Connecticut State line to and including the Connecticut River.

Reach 15: From the Connecticut River to and including the Housatonic River.

Reach 16: From the Housatonic River to the Connecticut-New York State line.

\section{SEGMENT 4}

From the Connecticut-New York States line to Cape May, N.J.

Reach 17: Consists of Long Island and a contributing area lying between the East River and the Hudson River drainage divide.

Reach 18: Lower New York Bay, which includes the Hudson, Hackensack, Passaic, and Raritan Rivers, and the spill from Croton Reservoir.

Reach 19: From Lower New York Bay to but exclusive of the Mullica River.

Reach 20: Mullica River to Cape May. 
SEGMENT 5

From Cape May to Cape Henry, Va.

Reach 21: Delaware Bay.

Reach 22: CoastaI area in Delaware, Maryland, and Virginia, between Cape Henlopen, Del., and Cape Charles, Va.

Reach 23: Chesapeake Bay.

\section{SEGMENT 6}

From Cape Henry to a point on the outer bank east of Moorhead City, N.C., at lat $34^{\circ} 40^{\prime}$

Reach 24: From Cape Henry to Iat $35^{\circ} 55^{\prime}$, which appears to be about the junction of Albemarle and Pamlico Sounds Because of the outer bank, however, the water from Albemarle Sound may have to flow south to the first break in the bank, which appears to be at lat $35^{\circ} 49^{\prime}$.

Reach 25: From lat $35^{\circ} 55^{\prime}$ to lat $34^{\circ} 40^{\prime}$. It includes Pamlico Sound and probably most of Core Sound.

\section{SEGMENT 7}

From lat $34^{\circ} 40^{\prime}$ (the vicinity of Moorhead City) to Georgetown, S.C., exclusive of the Pee Dee River

Reach 26: From lat $34^{\circ} 40^{\prime}$ to and including the Cape Fesr River. Reach 27: From the Cape Fear River to the Pee Dee River, but exclusive of both.

\section{SEGMENX 8}

Pee Dee River to but exclusive of the Altamaha River

Reach 28: Pee Dee River to the Edisto River, inclusive of both.

Reach 29: From the Edisto River to and including the Eavannah River.

Reach 30: From the Savannah River to the Altamaha River, but exclusive of both.

\section{SEGMENT 9}

Altamaha River to Cape Kennedy

Reach 31: Altamaha River to the St. Marys River, inclusive of both. Reach 32: From the St. Marys River to Cape Kennedy.

\section{SEGMENT 10}

From Cape Kennedy to Cape Sable, Fla.

Reach 33: From Cape Kennedy to and including the St. Lucie Canal and the St. Lucie River.

Reach 34: From the St. Lucie Canal to Cape Sable. 


\section{ESTIMATING DISCHARGE FROM UNGAGED AREAS \\ PERIOD 1951-60}

Discharge from ungaged areas was estimated, by years, on the basis of nearby gaged streams. Mean discharge for the year in a nearby gaged stream, or streams, expressed as cubic feet per second per square mile, was applied to the ungaged area. Insofar as possible, the gaged streams used were those having drainage areas of similar size as the ungaged area and at similar elevations, so that it could be inferred that the runoff characteristics of the gaged streams were somewhat similar to the ungaged area from which discharge was to be estimated.

In estimating the discharge from an ungaged area, as many streamflow records as available were used as a basis. The modal number of streamflow records available was three; for a very few areas only one streamflow record was available, or as many as five. With a very few exceptions, the mean discharges for the year from the gagad streams, expressed as cubic feet per second per square mile, were simply averaged and applied to the ungaged area. In the few exceptional areas, where there was great disparity in the discharge of the gaged streams, greater weight was given to streams that had drainage areas of comparable size.

It is recognized that this technique is subject to error, the error being variable from year to year and from place to place. The flow of small streams, particularly the monthly flow, tends to be erratic, even if their basins adjoin. For example, in any 1-month period the flow of one stream may be substantially less than in the preceding month, whereas in a nearby stream the flow may be greater than in the preceding month. However, the resulting errors introduced in the estimated yearly means of ungaged streams should be much smaller than in monthly means, and the errors in long-term means even smaller. During the period 1951-60 only about 25 percent of the total area of the Atlantic Coast drainage was ungaged; the corresponding estimated discharge was 24 percent of the total.

Extension of the study from 1950 back to 1931 required some modification of the procedures used in calculating the flow for the period 1951-60, owing to the fact that many streamflow records used in the 10-year study did not go back to 1931. Those modificatic 's are discussed briefly in the following section of the report.

\section{PERIOD 1931-50}

Insofar as possible, the same gaging-station records and the same procedures were used in calculating streamflow into the ocean for the 20-year period 1931-50 as for the 10-year period 1951-60. Along the New England coast most of the stations used in the 10-year study 
had records of the required length. For the comparatively few records that did not go back to 1931, it was possible to make extensions on the basis of nearby streams. South of New England, many records did not go back beyond 1951, or not far enough to warrant extension. Hence, for some areas along the coast south of New England it was found expedient to resort to graphical relations with long-record stations, rather than attempt to extend the records of many small streams. Graphical extensions were thus made for discharge from Long Island, Chesapeake Bay, Albemarle and Pamlico Sounds, reach 26 consisting mainly of the Cape Fear River, reach 27 consisting mainly of the Pee Dee River, reach 28 consisting mainly of the Santee River, and reach 29 consisting mainly of the Savannah River.

\section{REACH 17 (IONG ISLAND)}

Long Island and a 155 square-mile area in continental New York lying between the East and Hudson Rivers are designated as reach 17. A greater part of the streamflow from Long Island is southward directly into the ocean, and only a small part is northward into Long Island Sound, but as all the flow eventually discharges into th ocean, this study makes no attempt to separate the two components.

For the 10-year study, no streamflow records were available in Kings and Queens Counties. Streamflow from these counties was estimated largely on the basis of runoff rates in the Bronx River, although the high degree of urbanization has undoubtedly had a marked effect on the natural runoff rates. In addition to streamflow, water is wasted to the ocean in sewers. Some of this wasted water comes from the New York City municipal system and some is pumped from wells on Long Island. For the purpose of this study, no adjustment was made for either component of wastage. (All the water from the New York City system is assumed to be wasted into New York Bay. See "Municipal use" under the section "Adjustment for major diversions.")

For Nassau and Suffolk Counties, 18 gaging-station records were available in the 10-year study. Additional information, both quantitative and qualitative, was obtained from Brice (1951), Sawyer (1958), and from E. J. Pluhowski (oral commun., about Mar. 15, 195) who had participated in a ground-water study in Suffolk County.

Very little of the information used in the 10-year study was available for the period 1931-50, so that period was estimated from a curve of relation between the Hudson River and the streamflow from Long Island for the period 1951-60. The points scatter considerably, but a relation was loosely defined. The mean of the 20 years estimated graphically is 1,014 cfs (cubic feet per second), which, whon combined with the 10 -year mean of $1,106 \mathrm{cfs}$, gives a 30 -year mean of 1,045 
cfs. The 30-year mean thus obtained is about 6 percent less than the 10-year mean, which is consistent with other streamflow renords along this part of the coastline. (See also table 19.)

\section{REACH 23 (CHESAPEAKE BAY)}

In calculating the inflow to Chesapeake Bay for the 10-year period 1951-60, gaging-station records from 54 streams were used. These streamflow records accounted for about 80 percent of the drainage basin of the bay, ungaged areas constituting the remaining: 20 percent. Streamflow from the ungaged areas was estimated on the basis of records at nearby gaged streams.

Many of the records used in the 10-year study did not go back beyond 1951 , or at best only a few years. When the study was extended back to 1931, other procedures were necessary in lieu of the missing streamflow records. The best results were obtained from curves of relation between selected reference gaging stations and inflow to the bay for the 10-year period 1951-60. A requirement for a refer $n$ nce station was that its record go back to 1931 and hence could be use $d$ as a basis for estimating inflow to the bay during the period 1931-50. The stations used were Susquehanna River at Marietta, Pa.; Potomac River near Washington, D.C., adjusted for diversions; Rappahannock River near Fredericksburg, Va.; South Anna River near Ashland, Va.; Appomattox River near Petersburg, Va.; and James River near Richmond, Va., adjusted to include the flow of the James River and Kanawha Canal, which have a total drainage area of $4 \%, 634$ square miles, or 73 percent of the drainage area of the bay.

The bay was divided into segments by cross sections across the bay. Cross section 1 was just above the mouth of the Potomac, cross section 2 was just below the Potomac, cross section 3 was just above the James, and cross section 4 was across the mouth of the ka,y between Capes Charles and Henry. Inflow above cross section 1 was estimated from Susquehanna River at Marietta. The increment of inf' ow between cross sections 1 and 2 was estimated from Potomac River near Washington, D.C. The increment of inflow between cross sections 2 and 3 was estimated from Rappahannock River near Fredericksburg and South Anna River near Ashland, the Rappahannock River being given a weight of 2 on the basis of comparative drainage areas. The increment of inflow between cross sections 3 and 4 was estimated from James River near Richmond and Appomattox River near Petersburg, the Appomattox River being given a weight of 2.6 on the basis of comparative drainage areas. The total inflow to the bay is $\mathrm{tl}$ ? $\mathrm{n}$ the sum of the four increments.

To check the probable reliability of the estimates obtained by this procedure, the inflow to the bay was estimated for the years 1951-60 
and compared with the basic calculations in which all available streamflow records were used. Differences in the yearly means ranged from -8 percent to +7 percent, but the two 10 -year means agree within half a percent. It is assumed that the estimates for the 20 -yer $r$ period 1931-50 are within the same range of accuracy.

REACH 24 (ALBEMARLE SOUND)

The inflow to Albermarle Sound during the 20-year period 1931-50 was estimated from a curve of relation between the yearly inflow to the sound for the 10-year period 1951-60 and a weighted average of the flow at the gaging stations Nottoway River near Sebrell, Va., and Roanoke River at Roanoke Rapids, N.C. The Sebrell record was given a weight of 2.8 on the basis of the fact that its drainage area was more nearly comparable with that of the ungaged streams.

\section{REACH 25 (PAMLICO SOUND)}

The inflow to Pamlico Sound during the 20-year period of 1931-50 was estimated from a curve of relation between the flow at th: gaging stations Tar River at Tarboro, N.C., and Neuse River at Kinston, N.C., and the total yearly inflow to the sound for the 10-year period 195160 . Both stations were given equal weight.

\section{REACH 26 (CAPE FEAR RIVER)}

Reach $26(10,521 \mathrm{sq} \mathrm{mi})$ consists mainly of the Cape Fear River $(9,136 \mathrm{sq} \mathrm{mi}$ at mouth $)$. None of the gaging stations used in the 195160 study had records back to 1931 . The principal station, Cape Fear River at lock 3 near Tarheel, N.C., which has records beginning in 1938, was extended back to 1931 on the basis of the upstream station at Fayetteville. A curve of relation was then drawn between tr a yearly flow at the Tarheel station and the yearly inflow to the reacl during 1951-60, and from this relation curve, the inflow during 1931-50 was estimated on the basis of the Tarheel station.

\section{REACH 27 (PEE DEE RIVER)}

Reach 27 (18,562 sq mi) consists mainly of the Pee Dee River $(16,310$ $\mathrm{sq} \mathrm{mi}$ at mouth). As few of the gaging stations used in the 1951-60 study have records back to 1931, the outflow from reach 27 during the 20-year period 1931-50 was estimated from a curve of relation between a weighted yearly flow at four gaging stations and the yearly outflow from reach 27 during the period 1951-60. The stations used were Pee Dee River at Pee Dee, S.C.; Lynches River at Efongham, S.C.; Lumber River at Boardman, S.C.; and Black River at Kingstree, S.C.; which have a combined drainage area of 12,340 square miles. On the basis of comparative drainage areas, the flow at the last three stations was given double weight. 


\section{REACH 28 (SANTEE RIVER)}

Reach 28 (20,545 sq mi) consists mainly of the Santee River (15,700 sq mi at mouth). Owing to regulation and lack of streamf ow records, it was not possible to calculate the outflow from reach 28 for 1931-50 by the some procedure as for 1951-60. The outflow was estimated from a curve of relation between yearly flow of Santee River near Pineville and of reach 28 for the period 1951-60.

In order to use the gaging station Santee River near Pineville as a reference, it was necessary to construct an adjusted record of unregulated flow for the entire period 1931-60. The Santee River is completely regulated by Lake Marion just upstream from the Pineville gaging station, and the greater part of the flow of the river is diverted from Lake Marion to Lake Moultrie through the Lakes Marion-Moultrie diversion canal. Only the water releasel down the Santee River, which in most years is a small part of the total flow, passes the Pineville station.

Unregulated streamflow records upstream at Ferguson were available for 1931-41. As the drainage area at Ferguson is only 100 square miles less than at Pineville, the two sites are considered equivalent when Pineville is adjusted for regulation. The Ferg"son record ends with the 1941 water year. Storage in Lake Marion began in November 1941. The Pineville record begins in May 1942, but records of diversion in the Marion-Moultrie canal were not published until October 1943. Hence, for the purpose of this study, the water years 1942 and 1943 were cosidered as being missing at Pineville. An unregulated record at Pineville was then constructed as follows: for the period 1931-41, the observed flow at Ferguson was used; fo" the period 1944-60, the observed flow at Pineville was adjusted for diversion in the Marion-Moultrie canal and for change in contents in La ke Marion; and for the years 1942 and 1943, the flow was estimated from a curve of relation between Pineville, adjusted, and Saluda River roar Columbia, S.C., adjusted, based on the periods 1936-41 and 1944-45. Beginning with 1944 the Pineville record was adjusted by adling to the observed flow at the Pineville station the flow of the Marion-Moultrie canal, adjusted for change in contents in Lake Marion cmverted to equivalent cubic feet per second. If storage in Lake Marion decreased during the year, the equivalent amount of the decrease was subtracted because it had come out of storage rather than down the Santee River; conversely, if storage in Lake Marion increased, the equivalent amount was added. The adjusted mean thus obtained at Pineville for the 10year period $1951-60$ is about 11 percent less than the adjusted mean for the 30-year period 1931-60, which is consistent with other streamflow records along this part of the coastline. (See also table 19.)

A curve of relation was drawn between the adjusted Pineville flow 
and the outflow from reach 28 for the 10-year period 1951-60, and this relation was used to estimate the outflow from reach $\varepsilon ?$ for the period 1931-50 on the basis of adjusted Pineville flow for that period.

\section{REACH 29 (SAVANAAH RIVER)}

Reach $29(13,445 \mathrm{sq} \mathrm{mi})$ consists mainly of the Savannah River (10,600 sq mi at mouth). Outflow from the reach for the period 1931-50 was estimated from a curve of relation between tl , station Savannah River near Clyo, Ga., and the yearly outflow from the reach for the period 1951-60. A gap of 4 years (1934-37) in the Clro record was estimated on the basis of a curve of relation between the Clyo station $(9,850 \mathrm{sq} \mathrm{mi})$ and the Augusta station (7,508 sq mi).

\section{ADJUSTMENT FOR MAJOR DIVERSIONS}

\section{MUNICIPAT USE}

BOSTON

The figures showing the amount of waste from sewers that flowed into Boston Harbor were furnished by the Massachusetts Metropolitan District Commission. As nearly as can be ascertained, the waste is water that was diverted above measuring points on streams and hence is not included in the streamflow records. As actual, or historic, flow is used in this study, diversions were not traced to the stream or streams from which they originated, nor was any adjustment made to streamflow. The waste must, however, be added to obtain the flow of Massachusetts Bay into the ocean. Figures of waste were furnished for the years $1920-60$; for the 10 years $1951-60$ the waste averaged $537 \mathrm{cfs}$, and for the 30 years $1931-60$ it averaged $466 \mathrm{cfs}$.

\section{NEW YORK CITY}

Water for the New York City municipal supply is diverted above measuring points on streams and hence is not included in tha streamflow records. Except for spill at Croton Dam, all the Croton River is diverted at the dam to the municipal water system. (Sea p. I2).

Figures of water use and population for the years 1898-1951 were obtained from a report entitled "A Description of the Water-Supply System of the City of New York," by the New York Department of Water Supply, Gas and Electricity (1952). Figures of water use for the years 1952-60 were obtained from the New York Denartment of Water Supply; figures of population for those years were furnished by the Bureau of the Census. Although the figures of water use were used only for the period 1931-60 in calculating the flow into the bay (reach 18), earlier figures are available and they are shown in table 1. Figure 1 shows a graphical comparison between water use and population for the period 1900-60. 
I 12 CONTRIBUTIONS TO THE HYDROLOGY OF THE UNITED STATES

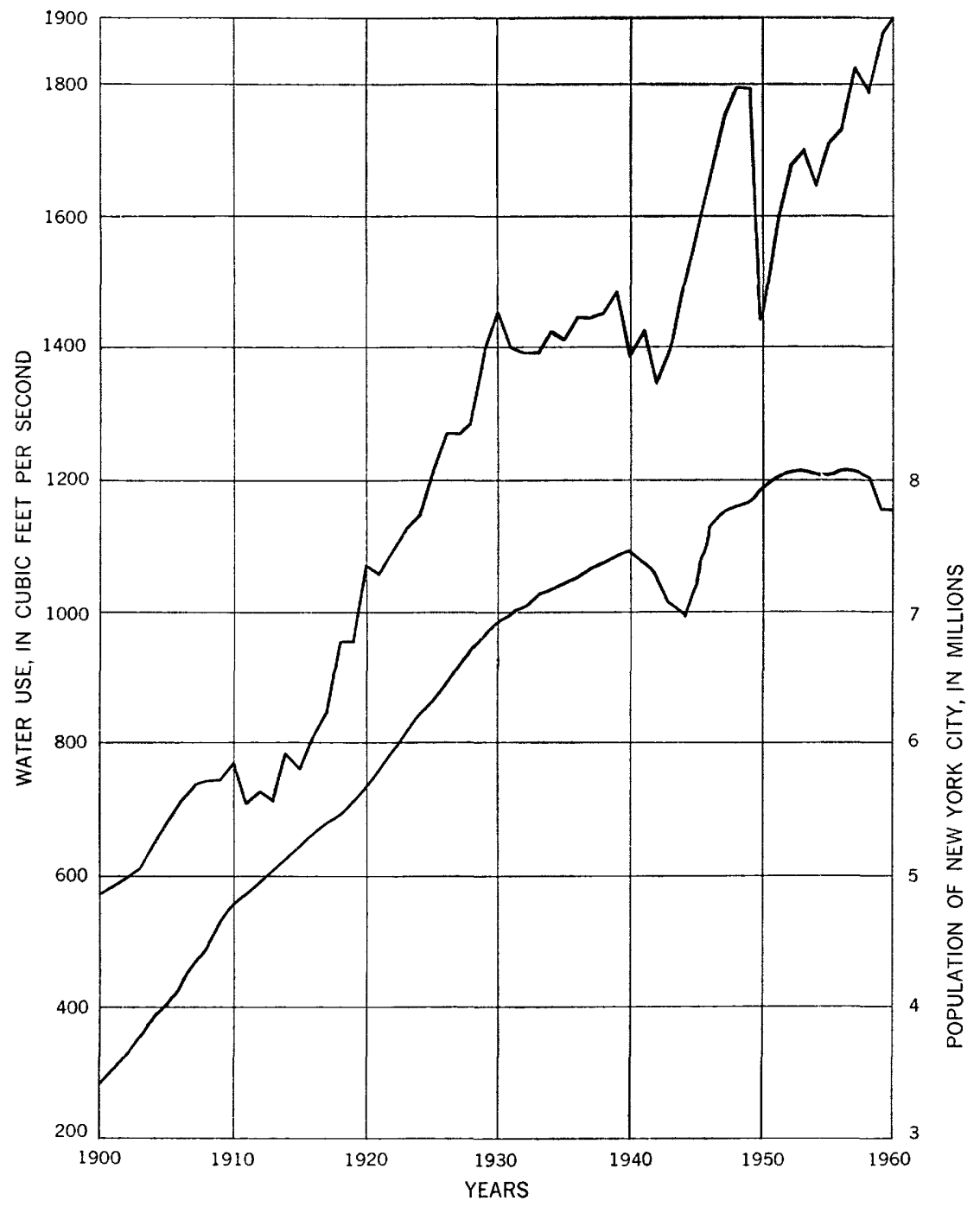

Fraure 1.-Use of water by New York City. 
served was $1,387,000$. According to the 1954 inventory by the U.S. Public Health Service, the water use was $199 \mathrm{mgd}$, and the population served was $1,261,000$. Therefore, it was assumed that the average water use during the decade 1951-60 was $205 \mathrm{mgd}$, or $318 \mathrm{cfs}$.

Water from the Gunpowder River, supplemented from the Susquehanna River, constitutes about 55 percent of the total, and the Patapsco River furnishes the remaining 45 percent. Water is taker out of the Gunpowder and Patapsco Rivers above the measuring points, so that the streamflow records do not include the diversions. Water from the Susquehamna is taken out downstream from the measuring point, so that no adjustment would be required for this diversion. It was assumed, however, that the supplemental water from the Susquehamna is so small in comparison with the Gunpowder diversion that the entire diversion of $318 \mathrm{cfs}$ can be added to the flow of Chesapeake Bay during the period 1951-60 without appreciable error. As the flow of Chesapeake Bay was calculated graphically for the period 1931-50 (see section on Chesapeake Bay), no separate adjustment was made for that period.

\section{WASHINGTON, D.c.}

The city of Washington takes its water from the Potomac River upstream from the gaging station near Washington D.C., and wastes its water back into the Potomac River downstream from the gaging station. The Potomac River streamflow records used in this report are adjusted for this diversion, so that no further adjustment for waste from Washington is applicable.

\section{CHESAPEAKE AND DELAWARE CANAT}

The Chesapeake and Delaware Canal is a sea-level navigation channel between the upper end of Chesapeake Bay and the Delaware River. Water in the canal may flow in either direction, depending upon the difference in the height of the tides at the ends of the canal.

A publication by the Corps of Engineers, Committee on Tidal Hydraulics, which is dated August 1965 and entitled "Inland Waterway Between Delaware River and Chesapeake Bay-Problem of Disposal of Material to Be Removed From a Portion of Channel in the Chesapeake Bay," states that "under present conditions $(27 \times 250$-foot channel), the Chesapeake and Delaware Canal carries approximately $43,000,000$ cubic feet more flow eastbound than it does westbound per tide cycle of 12.42 hours during normal tides." This net difference is equivalent to a little less than 1,000 efs. A pamphlet iss red by the Philadelphia District, Corps of Engineers, which is dated April 1967 and entitled "Inland Waterway, Delaware River to Chesapeake BayHistoric Chesapeake and Delaware Canal," states that "the mean 
range (of tide) at the Delaware River end is approximately $51 / 2$ feet while at the western end of the canal proper it is about 2 fe $* * *$. The mean level of the water surface at the western end is about 0.3 foot higher than mean river level in the Delaware at the eastern end."

Prior to 1935 the canal was 12 feet deep and the width ranged from 90 to 150 feet. Between 1935 and 1938 the dimensions were increased to 27 feet deep and 250 feet wide. In 1954, work began on deepening the canal to 35 feet and widening it to 450 feet; as of January 1, 1967, the work was about 51 percent complete. As the canal is a sea-level channel, it would seem reasonable to believe that the slore of the water surface is little affected by change in dimensions, and that the flow in the canal is somewhat proportional to the controlling, or minimum, cross section. Accordingly, the net eastward flow in the canal is estimated to be about as follows: $1931-35,200 \mathrm{cfs} ; 1936,500 \mathrm{cfs} ; 1937$, $800 \mathrm{cfs}$; and 1938-60, 1,000 cfs. When the enlargement now in progress is completed, the canal will likely carry proportionally more water than it does now.

As far as total flow into the ocean is concerned, it makes no clifference whether or not adjustment is made for diversion of water by the canal. Delaware Bay and Chesapeake Bay are both in segment 5 of the coastline (see table 8); both unadjusted and adjusted figures are shown for both bays (reaches 21 and 23 ). The total outflow from segment 5 is the same, regardless of which set of figures is used.

\section{DIVERSION FROM THE SANTEE RIVER TO THE COOPER RIVER}

Water is stored in Lake Marion (storage began in Novembэr 1941), 2.4 miles upstream from the gaging station Santee River near Pineville and diverted through the Lakes Marion-Moultrie diversion canal to Lake Moultrie (storage began in November 1941), from whence it is released into the West Branch Cooper River. Records of discharge in the canal began in October 1944.

The Cooper River basin occupies roughly half of an ungaged area of 1,800 square miles of coastal area lying between the basins of the Santee and Edisto Rivers. The discharge of the Santee and Edisto Rivers, the diversion from the Santee to the Cooper River, and the discharge originating within the 1,800-square-mile area are included in reach 28 , a breakdown of which is shown in table 2 for the 10-year period 1951-60. About half of the discharge from the 1,800-square-mile area is assumed to originate in the Cooper River basin.

The amount of water released into the Cooper River basin is equal to the discharge of the Marion-Moultrie canal adjusted for change in contents in Lake Moultrie. If storage in Lake Moultrie increased during the year, the equivalent amount in cubic feet per second was sub- 
tracted from the discharge of the Marion-Moultrie canal; conversely, if storage decreased, the equivalent amount was added. Records of release to the Cooper River basin are available since 1944. During the 17-year period 1944-60 the release ranged from 7,377 efs in 1955 to $19,920 \mathrm{cfs}$ in 1960 and averaged $13,770 \mathrm{cfs}$. Releases during 1951-60 are shown in table 2.

TABLE 2.-Components of discharge, in cubic feet per second, from reach 28

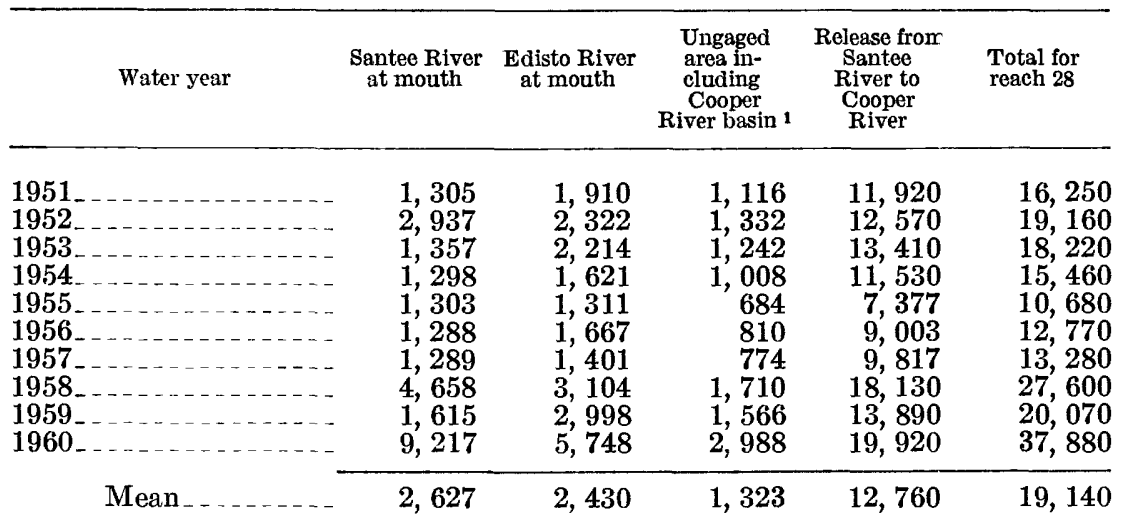

Drainage area in

square miles.

15,700

3,045

1,800

20,545

1 Approximately half of this discharge is assumed to originate in the Cooper River basin

STREAMFLOW

\section{SUMMARY OF STREAMFLOW INTO THE ATIANTIC OCEAN}

Streamflow from the United States into the Atlantic Ocean, between the St. Croix River, inclusive, and Cape Sable, Fla., averaged about 363,000 cfs during the 10-year period $1951-60$ and about $355,000 \mathrm{cfs}$ during the 30-year period 1931-60. Streamflow from the conterminous United States into the oceans and across the international boundaries was computed by Langbein (1949) as about $1,800,000 \mathrm{cfs}$ for the period 1921-45, and the Water Resources Council (1968) gives $1,860,000 \mathrm{cfs}$ as the annual natural runoff for the period 1931-60 from the same area. Hence, the flow into the Atlantic Ocean is roughly 20 percent of the flow from the conterminous United Stater

The area drained by streams flowing into the Atlantic Ocean is 288,339 square miles, including 625 square miles of the St. Croix River basin in New Brunswick and 114 square miles of the Connecticut River basin in Quebec, a little less than 10 percent of the area of the conterminous United States. Thus in terms of cubic feet per second per square mile, the flow into the Atlantic Ocean is about twice the national 
average of the flow that leaves the conterminous United States. Table 3 summarizes, by segments, streamflow into the Atlantic Ocean for each year of the 30-year period 1931-60. The table shows also the 30-year mean for each segment, and the segment means and yearly totals expressed in terms of cubic feet per second per square mile. Flow is not uniformly high or low along the entire coastline. In some segments the flow may be below average in any 1-year period and above average in other segments. However, in 1931, the year of lowest total flow, the flow in all segments was well below average, and in 1960, the year of highest total flow, the flow in all segments was well above average.

Total discharge to the ocean, in terms of cubic feet per second (from table 3), is plotted in figure 2. Although there apparently is \& very slight upward trend during the 30-year period, this trend is probably due to the fact that the period begins in a sequense of low years and ends in a sequence of high years. If the graph were extended both ways so as to include some higher years before 1931 and some lower years after 1960, the apparent upward trend would no doubt be nullified.

In terms of cubic feet per second per square mile, streamflow decreases rather progressively from north to south. It averaces nearly $2 \mathrm{cfs}$ along the Maine coast, about $1 \mathrm{cfs}$ along the North Carolina coast, and about $0.9 \mathrm{cfs}$ along the Florida coast.

In contrast to streamflow, precipitation increases from north to south. The normal statewide precipitation is about 42 inches in Maine, 49 inches in North Carolina, and 55 inches in Florida. Accordingly, the precipitation-runoff ratio decreases from about 0.6 in Maine to about 0.3 in North Carolina and to about 0.2 in Florida. This decrease in runoff from north to south nay be explained in pert by the corresponding increase in evaporation. According to U.S. Weather Bureau Technical Paper No. 37 (pl. 1) average annual Cless A pan evaporation averages about 25-30 inches in Maine, 50-55 inches in North Carolina, and 60-65 inches in Florida.

As pointed out by Hidore (1966), one cause of the decreasing runoff per unit area from north to south is the greater seepage into the coastal plain sediments (the coastal plain widens progressively from New Jersey southward to North Carolina). Proof of this is found in the existence of fresh water in the extension of the coastal plain aquifiers under the continental shelf (Manheim, 1967).

Tables 4-13 show the breakdown of discharge by reaches for each of the 10 segments.

Many streams that discharge from the mainland empty into a bay or a sound, instead of directly into the ocean. As the outflow from bays and sounds is not measured directly, the outflow from such bodies of water to the ocean is considered as being equivalent to the tctal inflow 
๓

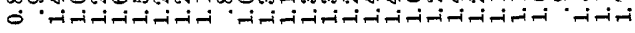

్ㅏ융잉유.

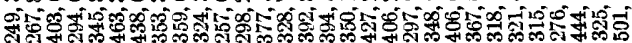

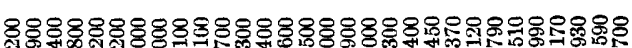

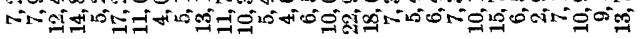

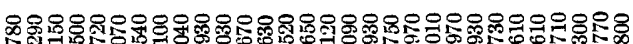

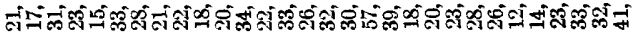

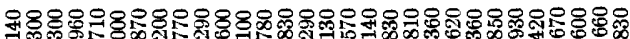

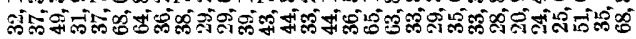

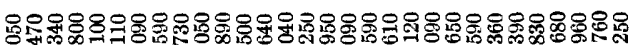

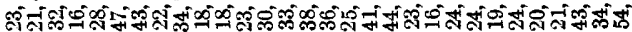

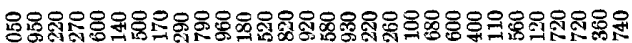

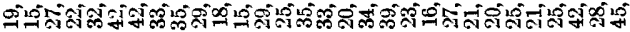

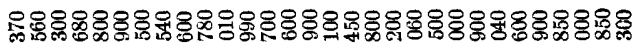

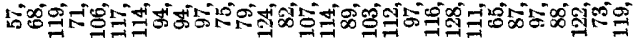

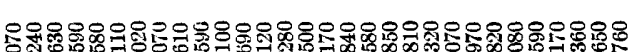
तี

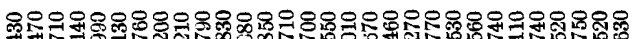

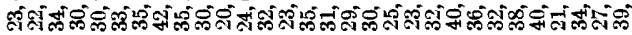

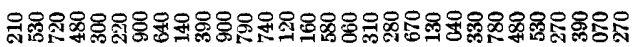

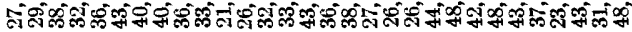

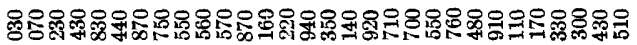

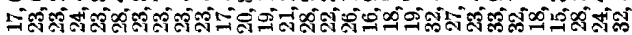
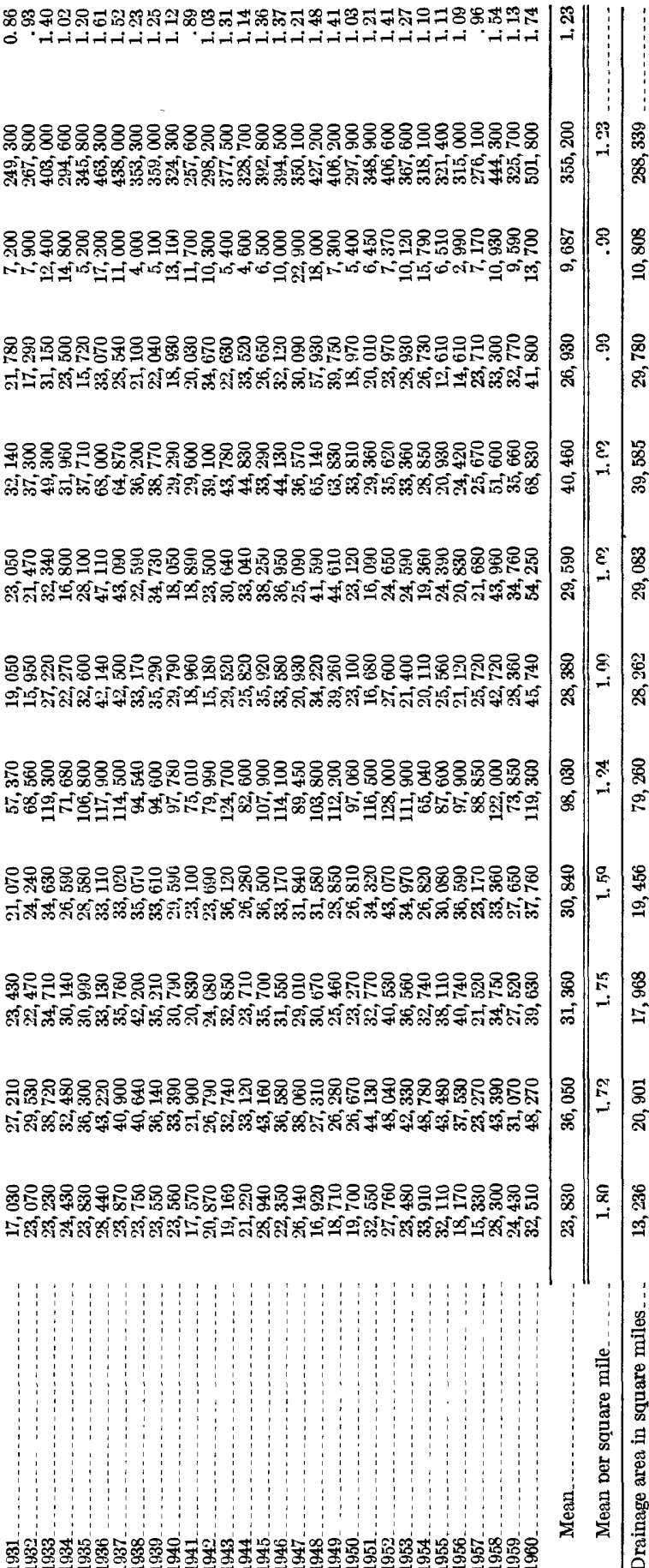


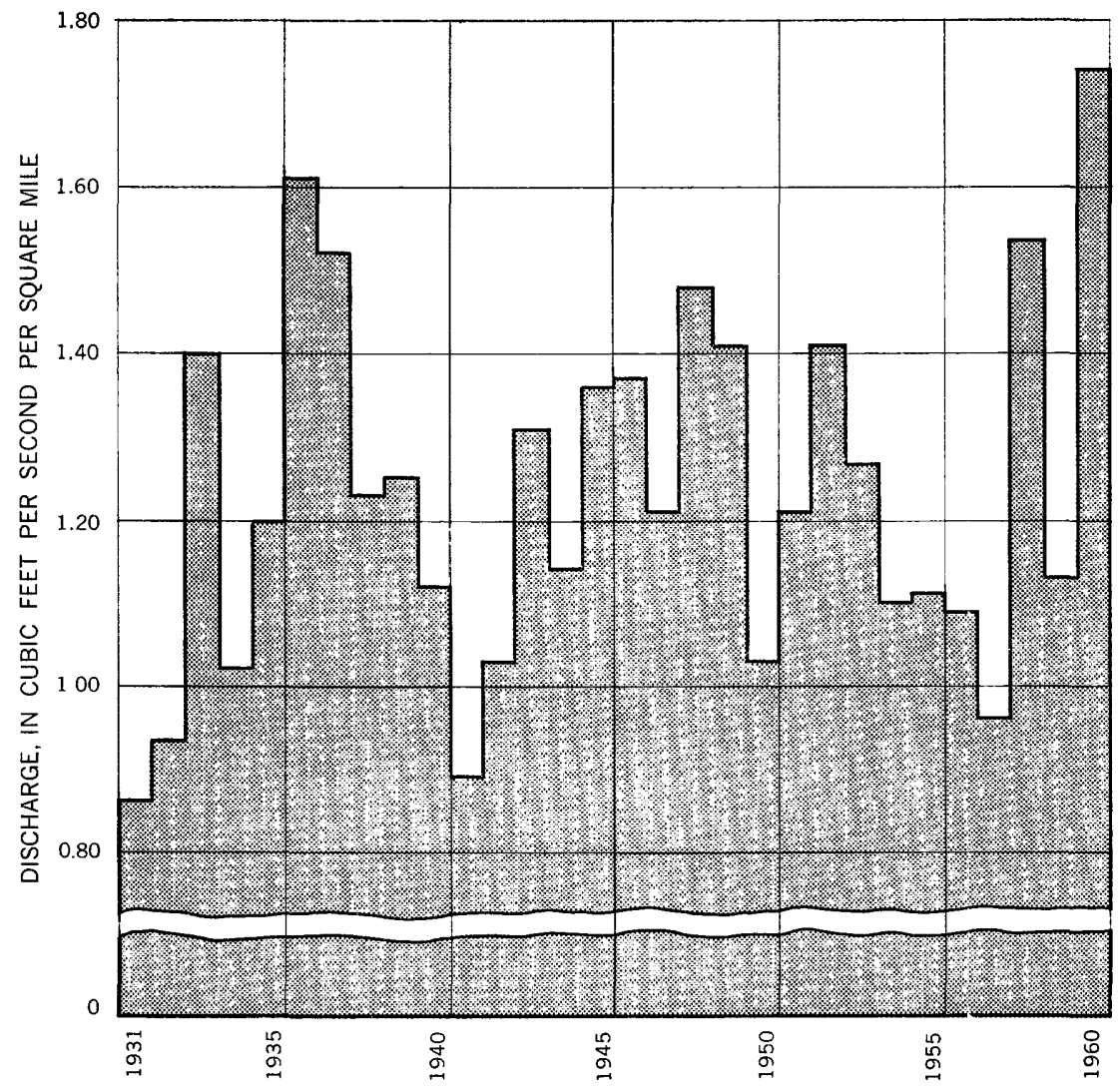

Fraure 2.-Pattern of streamflow into the Atlantic Ocean, 1931-60.

to those bodies. The inflow to a bay or a sound and the outflow to the ocean are theoretically equivalent if adjustments were made for rainfall on and evaporation from the water surface of that body and for ground-water inflow. These items are probably relatively small, on the average, and probably constitute only a small percentage of the total inflow to that body of water. Hence, in this study no ad ustments are attempted.

Chesapeake Bay is the largest bay discharging into the ocean, so that it is discussed briefly as an example of the probable magnitude of the adjustments that would be applicable for rainfall, evaporation, and ground-water inflow. The average annual rainfall on Chesapeake Bay is in the range of $32-48$ inches (U.S. Weather Bureau, 1955), and the average annual evaporation is in the range of $36-40$ inches (U.S. Weather Bureau, 1959, pl. 2). If the average annual rainfall is assumed to be 40 inches and the average annual evaporation, 38 inches, 
the net rainfall is only 2 inches, which on the 2,800 sque re miles of water surface of the bay is equivalent to about $400 \mathrm{cfs}$, or about onehalf of 1 percent of the average inflow to the bay. The U.S. Geological Survey has estimated the upward leakage into the bay from artesian aquifers lying beneath it to be about $250 \mathrm{cfs}$ and hes qualified the estimate as possibly being in error by an order of magnitude, but the Survey has made no estimate of direct seepage along the shore ( E. G. Otten, written commun., Aug. 17, 1967). Thus it appears that, on the average, the net effect of rainfall, evaporation, and groundwater inflow is small, percentagewise, although if a mcnth of low streamflow were also a month of low rainfall and high evaporation, the net effect might constitute a large percentage of the total inflow.

In calculating the flow to the ocean for the period 1951-60, the most downstream gaging-station records of required length were used. These records were about 240 in number and accounted for about threefourths of the drainage area between the Canadian border and Cape Kennedy. Flow from the ungaged areas between the Canadian border and Cape Kennedy was estimated on the basis of nearby gaging stations. Between Cape Kennedy and Cape Sable the streamflow to the ocean is so complicated by canals and drainage facilitiss that the author made no attempt to calculate flow to the ocean on the basis of streamflow records; for this part of the coastline, flow racords were furnished by the Tallahassee office of the U.S. Geological Survey.

\section{DISCHARGE OF THE HUDSON RIVER AT MOUTH, 1890-1960}

Discharge of the Hudson River at mouth was computed for the years 1890-1960. Streamflow records available were as follows: Hudson River at Mechanicville, 1890-1955; Mohawk River at Cohoes (at Vischer Ferry Dam prior to 1919), 1899-1960; Hudson River at Green Island, 1947-60; and records from seven small streams below Green Island, 1929-60. The gaging stations on these seven streams were as follows: Poesten Kill near Troy, 89 square miles; Kinderhook Creek at Rossman, 329 square miles; Catskill Creek at Oakhill, 98 square miles; Esopus Creek at Coldbrook, 192 square miles; Ror dout Creek at Rosendale, 386 square miles; Wallkill River at Gardiner, 711 square miles; and Wappinger Creek near Wappinger Falls, 182 square miles.

These seven records were used as a basis for estimating the ungaged flow below the Mohawk River prior to 1947 and below Green Island thereafter for the period 1929-60. A graphical relation between the flow at Mechanicville and the flow at mouth for the period 1929-55 was used to estimate the flow at mouth for the period 1890-1928. Discharge of the Hudson River is shown in table 14. 
TABLE 4.-Discharge, in cubic feet per second, from reaches 1-4, segment 1

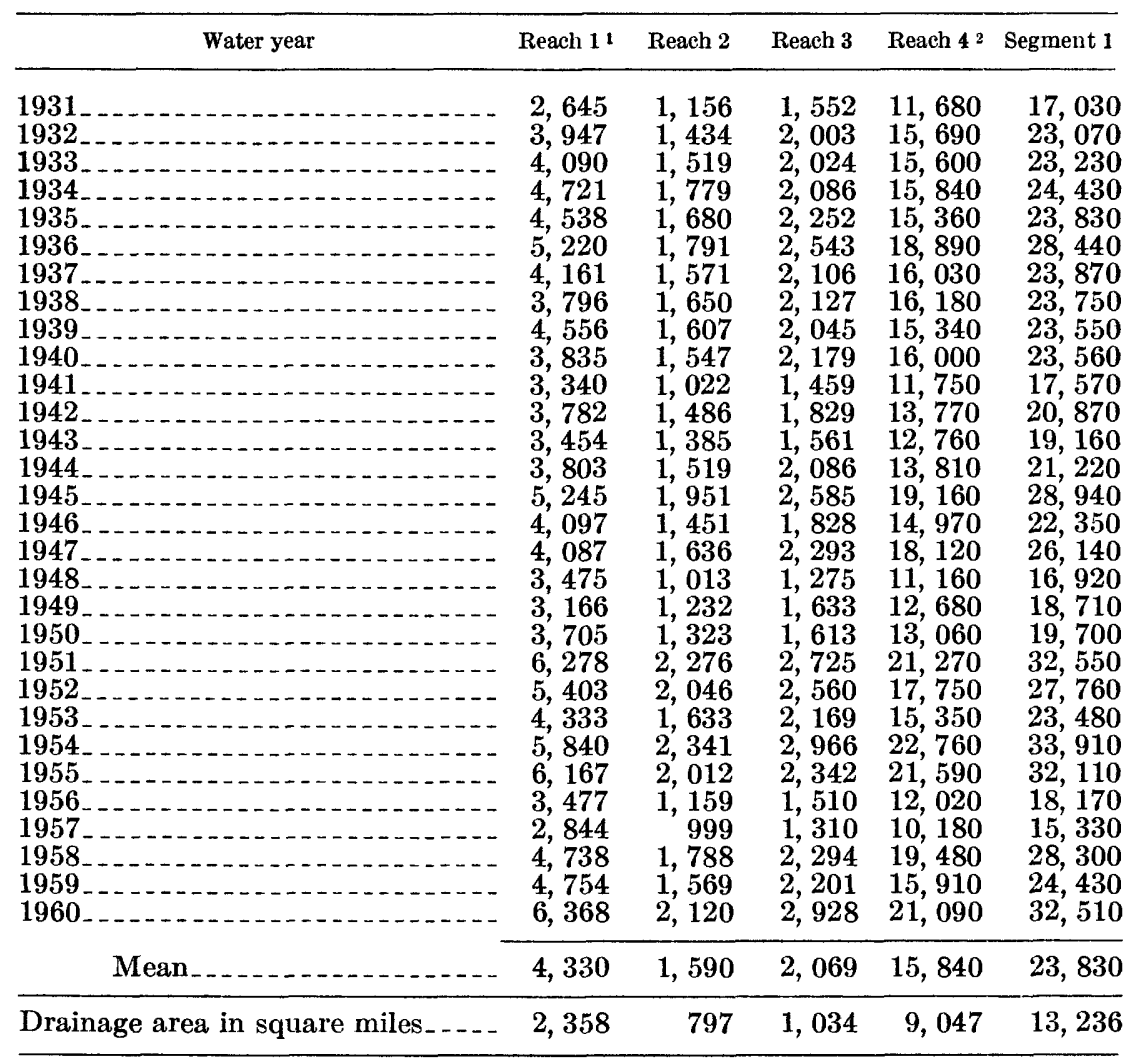

I Includes 625 square miles of St. Croix River basin in New Brunswick and 114 square miles of Connecticut River basin in Quebec.

2 Penobscot Bay. 
TABLE 5.-Discharge, in cubic feet per second, from reaches $5-10$, segment $\mathscr{2}$

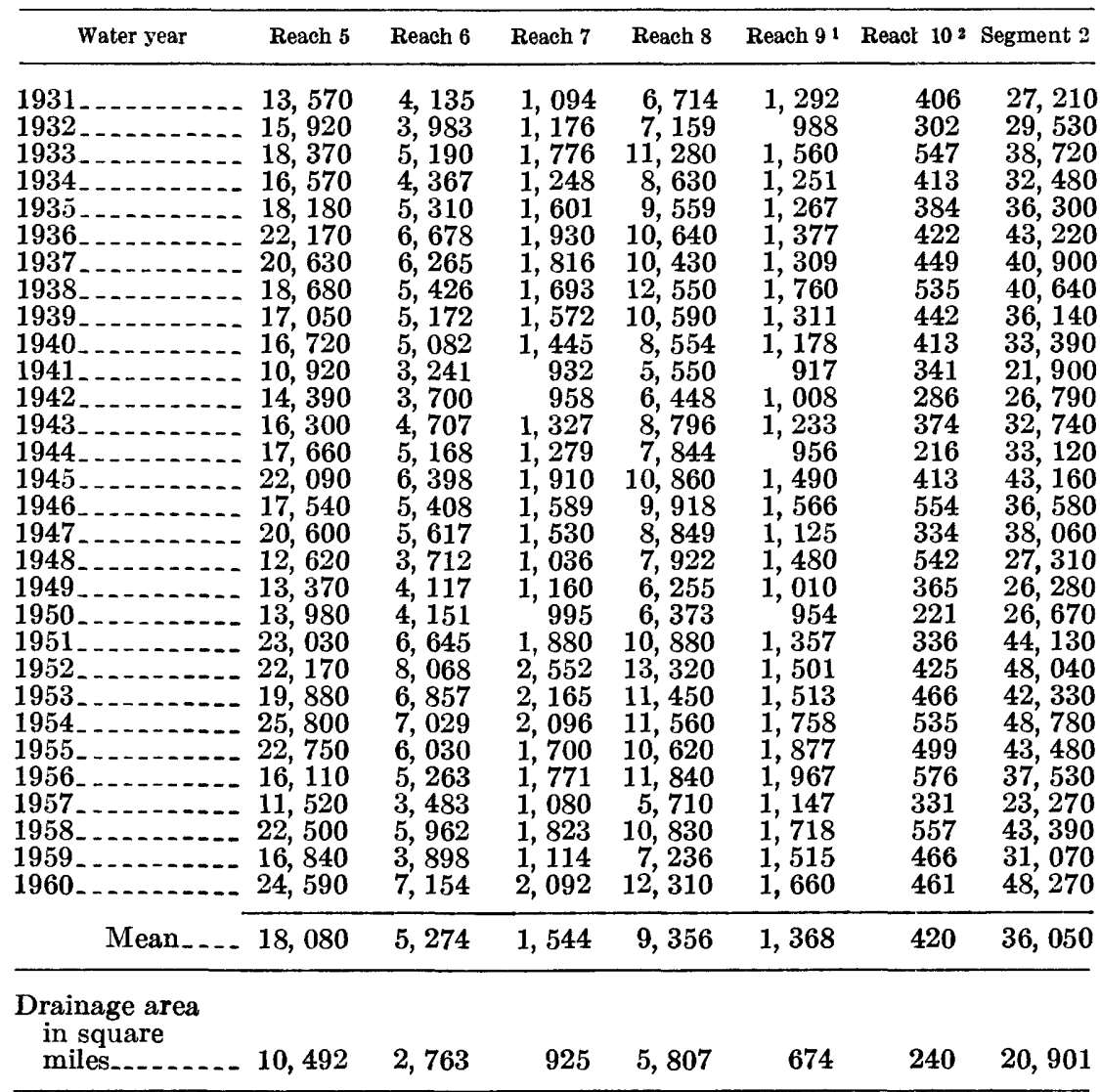

1 Massachusetts Bay Includes sewage waste from Boston, averaging 466 cfs during 1981- -30 . (See table 16). 2 Cape Cod Bay. 
TABLE 6.-Discharge, in cubic feet per second, from reaches 11-16, seiment 3

\begin{tabular}{|c|c|c|c|c|c|c|c|}
\hline Water year & Reach 11 & Reach 12 & Reach 13 & Reach 14 & Reach 15 & Reach if & Segment 3 \\
\hline $\begin{array}{l}1931 \\
1932 \\
1933 \\
1934 \\
1936 \\
1937\end{array}$ & $\begin{array}{r}1,102 \\
821 \\
1,485 \\
1,122 \\
1,044 \\
1,148 \\
1,219 \\
1,455 \\
1,199 \\
1,122 \\
927 \\
777 \\
1,019 \\
588 \\
1,122 \\
1,507 \\
906 \\
1,473 \\
991 \\
600 \\
912 \\
1,154 \\
1,265 \\
1,454 \\
1,346 \\
1,564 \\
899 \\
1,514 \\
1,264 \\
1,251\end{array}$ & $\begin{array}{l}2,448 \\
1,689 \\
3,457 \\
2,660 \\
2,789 \\
2,847 \\
2,926 \\
3,897 \\
2,953 \\
2,553 \\
1,882 \\
1,825 \\
2,437 \\
1,441 \\
2,801 \\
3,155 \\
2,076 \\
3,182 \\
2,100 \\
1,556 \\
2,537 \\
3,095 \\
3,049 \\
3,205 \\
3,549 \\
3,938 \\
1,958 \\
3,330 \\
2,832 \\
3,108\end{array}$ & $\begin{array}{r}493 \\
412 \\
733 \\
659 \\
659 \\
716 \\
762 \\
1,111 \\
733 \\
768 \\
516 \\
453 \\
596 \\
423 \\
687 \\
720 \\
498 \\
789 \\
530 \\
445 \\
555 \\
720 \\
763 \\
792 \\
806 \\
892 \\
487 \\
880 \\
719 \\
629\end{array}$ & $\begin{array}{l}16,130 \\
16,840 \\
24,130 \\
20,990 \\
22,040 \\
24,120 \\
25,610 \\
28,760 \\
24,910 \\
21,400 \\
14,430 \\
17,370 \\
23,520 \\
17,900 \\
25,360 \\
21,620 \\
21,820 \\
20,250 \\
17,440 \\
17,400 \\
23,620 \\
28,710 \\
25,470 \\
23,520 \\
26,500 \\
27,610 \\
15,240 \\
24,120 \\
18,620 \\
29,140\end{array}$ & $\begin{array}{l}2,928 \\
2,461 \\
4,388 \\
4,055 \\
3,949 \\
3,770 \\
4,600 \\
6,105 \\
4,763 \\
4,284 \\
2,689 \\
3,147 \\
4,604 \\
2,933 \\
5,140 \\
3,982 \\
3,280 \\
4,321 \\
3,890 \\
2,981 \\
4,548 \\
6,013 \\
5,305 \\
3,423 \\
5,285 \\
5,853 \\
2,595 \\
4,228 \\
3,638 \\
4,949\end{array}$ & $\begin{array}{l}327 \\
247 \\
517 \\
651 \\
50 \varepsilon \\
53 \AA \\
644 \\
87 c \\
654 \\
664 \\
38 \varepsilon \\
504 \\
671 \\
42 \AA \\
594 \\
562 \\
43 \AA \\
651 \\
507 \\
284: \\
594 \\
837 \\
70 \varepsilon \\
347 \\
62 \varepsilon \\
87 \varepsilon \\
344: \\
67 \% \\
44 \AA \\
55 \varepsilon\end{array}$ & $\begin{array}{l}23,430 \\
22,470 \\
34,710 \\
30,140 \\
30,990 \\
33,130 \\
35,760 \\
42,200 \\
35,210 \\
30,790 \\
20,830 \\
24,080 \\
32,850 \\
23,710 \\
35,700 \\
31,550 \\
29,210 \\
30,670 \\
25,460 \\
23,270 \\
32,770 \\
40,530 \\
36,560 \\
32,740 \\
38,110 \\
40,740 \\
21,520 \\
34,750 \\
27,520 \\
39,630\end{array}$ \\
\hline Mean_. & 1,142 & 2,709 & 665 & 22,150 & I & 55 & 1,360 \\
\hline
\end{tabular}

Drainage area

in square

$\begin{array}{llllllll}\text { miles_..... } & 653 & 1,505 & 338 & 12,825 & 2,329 & 31 \varepsilon & 17,968\end{array}$ 
TABLE 7.-Discharge, in cubic feet per second, from reaches 17-20, segment 4

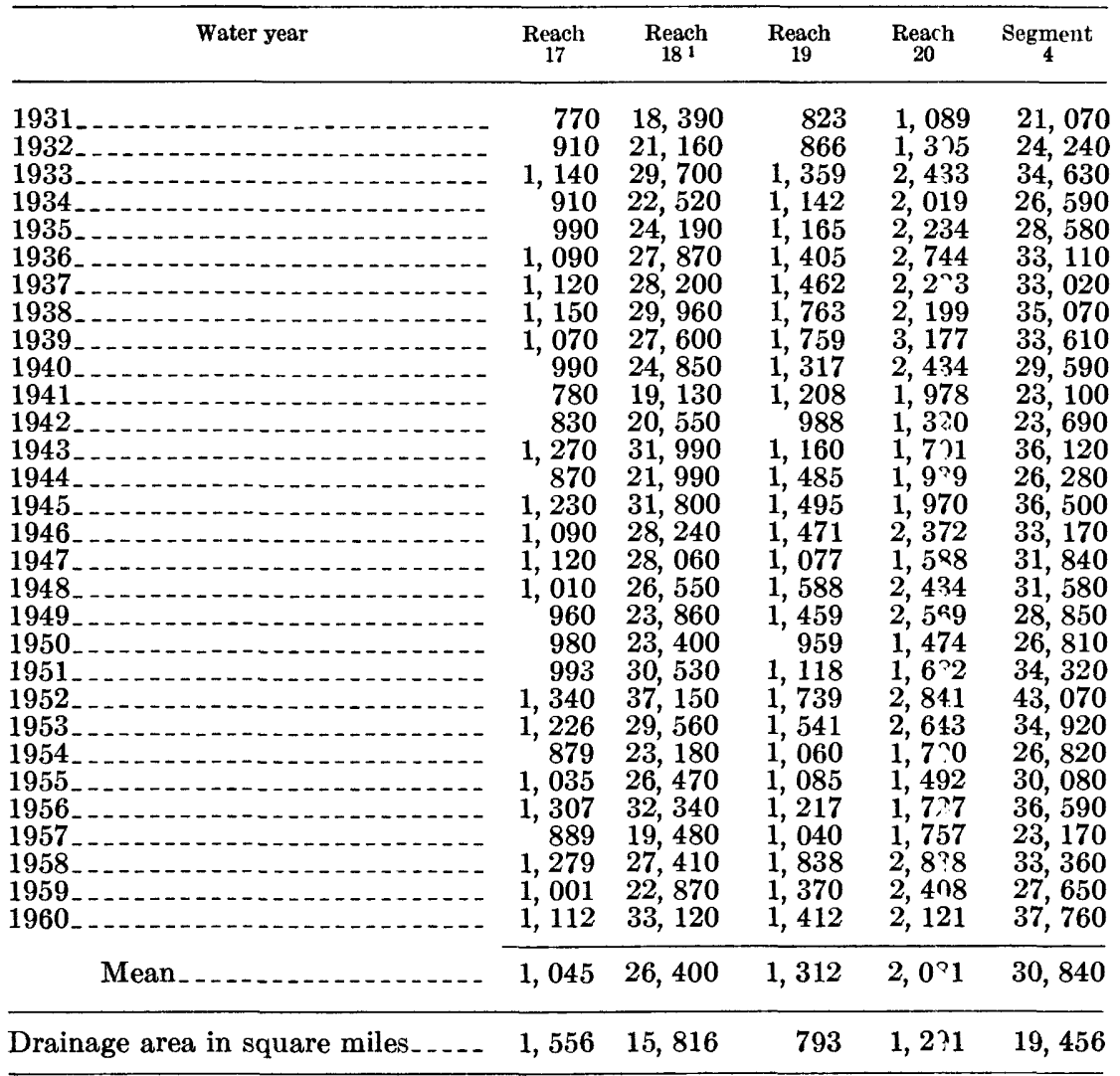

Includes water used by New York City (see table 1) averaging 1,578 cfs during 1931-6气. 
TABLE 8.-Discharge, in cubic feet per second, from reaches 21-23, segment 5

\begin{tabular}{|c|c|c|c|c|c|c|}
\hline \multirow{2}{*}{ Water year } & \multicolumn{2}{|c|}{$\begin{array}{l}\text { Reach 21, Delaware } \\
\text { Bay }\end{array}$} & \multirow{2}{*}{ Reach 22} & \multicolumn{2}{|c|}{$\begin{array}{l}\text { Reach 23, Chesapeak? } \\
\text { Bay } 1\end{array}$} & \multirow{2}{*}{ - Segment 5} \\
\hline & $\begin{array}{l}\text { Un- } \\
\text { adjusted } 2\end{array}$ & Adjusted 2 & & $\begin{array}{c}\text { Un- } \\
\text { adjusted } 2\end{array}$ & Adjusted ${ }^{2}$ & \\
\hline 931 . & 12,570 & 12,770 & 497 & 44,300 & $44,10 \mathrm{C}$ & 57,370 \\
\hline & 13,320 & 13, & & 54,700 & & 68,560 \\
\hline 皮 & 26,200 & 26,400 & 1,877 & 91,200 & $91,00 \mathrm{C}$ & 119,300 \\
\hline 90 & 17,790 & 17,990 & 1,194 & 52,700 & $52,50 \mathrm{C}$ & 71,680 \\
\hline 335 & 20,880 & 21,080 & 1,510 & 84,400 & $84,20 \mathrm{C}$ & 106,800 \\
\hline 936 & 25,100 & 25,600 & 1,923 & 90,900 & $90,40 C$ & 117,900 \\
\hline 937. & 19,940 & 20,740 & 994 & 93,600 & $92,80 c$ & 114,500 \\
\hline 938 & 23,290 & 24,290 & 445 & 69,800 & & 94,540 \\
\hline 1939 & 23,210 & 24,2 & 1,793 & 69,600 & $68,60 \mathrm{C}$ & 94,600 \\
\hline 0 & 20,330 & 21, & 1,352 & & & 97,780 \\
\hline 1941 & 16,310 & 17,310 & 999 & 57,700 & $56,70 c$ & 75,010 \\
\hline $0 a^{\circ}$ & 16,980 & 17 & 706 & 62,300 & & 79,990 \\
\hline 194 & 23,500 & 24,5 & 1,398 & 99,800 & $98,80 \mathrm{C}$ & 124,700 \\
\hline M & 17,000 & 18 & 799 & 00 & & 82,600 \\
\hline 19 & 23,950 & 24 & 1,343 & 82,600 & $81,60 C$ & 107,900 \\
\hline 94 & 22,980 & 23 & 1,561 & 00 & 00 & 114,100 \\
\hline 94 & 20,440 & 21,440 & 813 & 200 & 67 & 89,450 \\
\hline & 22,820 & 23 & 1,5 & 00 & C & 103,800 \\
\hline 194 & 20,340 & 21 & 1,695 & 90,200 & & 112,200 \\
\hline 95 & 17,980 & & 883 & & 77 & 97,060 \\
\hline 195 & 23,550 & 24, & 683 & 220 & 91 , & 116,500 \\
\hline $95^{\circ}$ & 31440 & 32,4 & 1,580 & 010 & & \\
\hline 195 & 25,880 & 26,8 & 1,134 & 84,850 & 83 & 111,900 \\
\hline & 15,040 & & 715 & & & 65,040 \\
\hline & & 19 & 855 & 68,690 & & 87,600 \\
\hline & & 23 & 9 & & & 97,900 \\
\hline & 16,390 & 17,3 & 1,296 & 71,160 & $70,16 \mathrm{C}$ & 88,850 \\
\hline & 23,730 & & 2,0 & & & 122,000 \\
\hline & 16,370 & 17, & 1,1 & 10 & & 73,850 \\
\hline 1960 & 23,860 & 24,860 & 1,463 & 93,930 & $92,93 \mathrm{C}$ & 119,300 \\
\hline 10 & 20,730 & $21,5,0$ & 1,228 & 76,070 & $75,23 \mathrm{C}$ & 98,030 \\
\hline
\end{tabular}

Drainage area in square

miles.

$$
12,855
$$

929

65,476

79,260

1 Includes water diverted from Gunpowder and Patapsco Rivers above gaging stations by city of Baltimore and wasted into Bay, estimated at $318 \mathrm{cfs}$ during 1951-60; discharge into bay determined graphically for 1931-50, so no separate estimate of wastage made for that period.

2 Adjustment is for water carried from Chesapeake Bay to Delaware River by Chesapeake and Delaware Canal, estimated at $200 \mathrm{cfs}$ in 1931-35, $500 \mathrm{cfs}$ in 1936, $800 \mathrm{cfs}$ in 1937, and 1,000 cfs in 1938-60. Ad justment not applicable to total for segment. 
TABLE 9.-Discharge, in cubic feet per second, from reaches 24 and 25 , segment 6

\begin{tabular}{|c|c|c|c|c|c|c|c|}
\hline \multirow{3}{*}{$\begin{array}{c}\text { Water year } \\
1931\end{array}$} & \multirow{2}{*}{$\frac{\text { Reach } 241}{10,900}$} & \multicolumn{2}{|c|}{ Reach 252 Segment 6} & \multicolumn{2}{|c|}{ Water year Reach 24} & \multicolumn{2}{|c|}{ Rearh $25^{2}$ Segment 6} \\
\hline & & & & 1 & 60 & & \\
\hline & & & & & & & \\
\hline & & 9, & 20 & 19 & & & 300 \\
\hline & 14 & 7, & 2,270 & 19 & 12 , & & 21,400 \\
\hline & 21 & 11,4 & 32,600 & & & & 20 \\
\hline & 25,060 & $17, \mathrm{C}$ & 42 & & 14,440 & 11, & 25 , \\
\hline & 24,140 & 18,3 & 42 & 19 & & & 21,120 \\
\hline & 23,540 & 9,6 & 33 & 195 & 17 & & 25,720 \\
\hline & & 14, & 3 & 19 & 0 & 16 , & 20 \\
\hline & 21, & 8, & & & & & \\
\hline 194 & 12,580 & 6, & 18 & 1960 & 25,6 & & 45,74 \\
\hline & 10,210 & 4,970 & & & & & \\
\hline 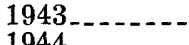 & 17,660 & 11,860 & 29 , & Mean.- & & & \\
\hline & $\begin{array}{l}16,040 \\
21,750\end{array}$ & $\begin{array}{r}9,780 \\
14,170\end{array}$ & $\begin{array}{l}25, \\
35\end{array}$ & Dra & & & \\
\hline & 20,510 & 13,070 & & $\operatorname{ar}$ & & & \\
\hline & 13,520 & 7,410 & 20,930 & & & & \\
\hline & & & & miles_ & 51 & 10,611 & 28,262 \\
\hline & & & & & & & \\
\hline
\end{tabular}

1 Albemarle Sound.

2 Pamlico Sound.

TABLE 10.-Discharge, in cubic feet per second, from reaches 26 and 27, segment 7

\begin{tabular}{|c|c|c|c|c|c|c|c|}
\hline Water year & Reach 26 & Reach 27 & Segment 7 & Water year & Reach 26 & Reach 27 & Segment 7 \\
\hline \multirow{18}{*}{$\begin{array}{l}1931 \\
1932 \\
1933 \\
1934 \\
1935 \\
1936 \\
1937 \\
1938 \\
1939 \\
1940 \\
1941 \\
1942 \\
1943 \\
1944 \\
1945 \\
1946 \\
1948 \\
1949\end{array}$} & \multirow{18}{*}{$\begin{array}{r}8,880 \\
7,960 \\
10,600 \\
6,900 \\
11,250 \\
18,580 \\
17,180 \\
7,360 \\
14,390 \\
7,140 \\
6,500 \\
6,600 \\
12,050 \\
13,420 \\
15,690 \\
14,770 \\
9,380 \\
13,880 \\
16,900\end{array}$} & \multirow{18}{*}{$\begin{array}{r}14,170 \\
13,510 \\
21,740 \\
9,900 \\
16,850 \\
28,530 \\
25,910 \\
15,230 \\
20,340 \\
10,910 \\
12,390 \\
16,900 \\
13,590 \\
19,620 \\
22,560 \\
22,180 \\
15,710 \\
27,710 \\
27,710\end{array}$} & \multirow{18}{*}{$\begin{array}{l}23,050 \\
21,470 \\
32,340 \\
16,800 \\
28,100 \\
47,110 \\
43,090 \\
22,590 \\
34,730 \\
18,050 \\
18,890 \\
23,500 \\
30,640 \\
33,040 \\
38,250 \\
36,950 \\
25,090 \\
41,590 \\
44,610\end{array}$} & 1950 & 9,020 & 14 & 23,120 \\
\hline & & & & 195 & & & 16,090 \\
\hline & & & & 1952 & 9,368 & & \\
\hline & & & & 1953. & 8,810 & 15 & 24,590 \\
\hline & & & & 1954 & 7,3 & 12 , & 19,360 \\
\hline & & & & 195 & 11,800 & 12 & 24,390 \\
\hline & & & & 1956 & 8,797 & 12, & 20,830 \\
\hline & & & & 1957. & 9,1 & 12 & 21,680 \\
\hline & & & & 1958 & 16,010 & 27,950 & 43,960 \\
\hline & & & & 1959 & 14,390 & & 34,760 \\
\hline & & & & 1960 & 18,860 & 35,390 & 54,250 \\
\hline & & & & \multirow{2}{*}{\multicolumn{2}{|c|}{ Mean_-- 11,290}} & & 29,590 \\
\hline & & & & & & & \\
\hline & & & & \multirow{5}{*}{$\begin{array}{c}\text { Drainage } \\
\text { area in } \\
\text { square }\end{array}$} & & & \\
\hline & & & & & & & \\
\hline & & & & & & & \\
\hline & & & & & 10,521 & 18,562 & 29,083 \\
\hline & & & & & & & \\
\hline
\end{tabular}


TABLE 11.-Discharge, in cubic feet per second, from reaches 28-30, segment 8

\begin{tabular}{|c|c|c|c|c|}
\hline Wate & Reach 28 & Reach 29 & Reach 30 & Segment 8 \\
\hline $\begin{array}{l}1931 \\
1932\end{array}$ & $\begin{array}{l}18,470 \\
20,700 \\
28,920 \\
17,850 \\
22,100 \\
35,310 \\
35,060 \\
20,600 \\
21,900 \\
13,650 \\
15,850 \\
20,420 \\
24,100 \\
22,850 \\
20,560 \\
24,790 \\
18,140 \\
30,440 \\
33,520 \\
19,680 \\
16,250 \\
19,160 \\
18,220 \\
15,460 \\
10,680 \\
12,770 \\
13,280 \\
27,600 \\
20,070 \\
37,880\end{array}$ & $\begin{array}{r}10,400 \\
13,110 \\
15,730 \\
11,000 \\
12,200 \\
23,250 \\
21,040 \\
12,690 \\
13,180 \\
12,270 \\
10,430 \\
13,180 \\
15,770 \\
15,590 \\
10,050 \\
15,430 \\
13,410 \\
22,860 \\
23,000 \\
12,250 \\
10,060 \\
12,750 \\
10,740 \\
10,290 \\
8,006 \\
8,648 \\
9,515 \\
16,860 \\
11,290 \\
22,340\end{array}$ & $\begin{array}{r}3,273 \\
3,489 \\
4,651 \\
3,111 \\
3,410 \\
9,436 \\
8,768 \\
2,907 \\
3,686 \\
3,367 \\
3,323 \\
5,496 \\
3,906 \\
6,391 \\
2,684 \\
3,911 \\
5,024 \\
11,840 \\
7,309 \\
1,881 \\
3,049 \\
3,709 \\
4,403 \\
3,101 \\
2,248 \\
2,997 \\
2,873 \\
7,141 \\
4,305 \\
8,610\end{array}$ & $\begin{array}{l}32,140 \\
37,300 \\
49,300 \\
31,960 \\
37,710 \\
68,000 \\
64,870 \\
36,200 \\
38,770 \\
29,290 \\
29,600 \\
39,100 \\
43,780 \\
44,830 \\
33,290 \\
44,130 \\
36,570 \\
65,140 \\
63,830 \\
33,810 \\
29,360 \\
35,620 \\
33,360 \\
28,850 \\
20,930 \\
24,420 \\
25,670 \\
51,600 \\
35,660 \\
68,830\end{array}$ \\
\hline Mean & 21,880 & 13,910 & 4,677 & 40,460 \\
\hline Drainage area in square miles.....- & 20,545 & 13,445 & 5,595 & 39,585 \\
\hline
\end{tabular}

TABLE 12.-Discharge, in cubic feet per second, from reaches 31 and 32 , segment 9

\begin{tabular}{|c|c|c|c|c|c|c|c|}
\hline Wa & Reach 31 & Reach 32 & Segment 9 & Water year & Reach 31 & Reach 32 & Segment 9 \\
\hline \multirow{18}{*}{$\begin{array}{l}1931 \\
1932 \\
1933 \\
1934 \\
1935 \\
1936 \\
1937 \\
1938 \\
1939 \\
1940 \\
1941 \\
1942 \\
1943 \\
1944 \\
1945 \\
1946 \\
1947 \\
1948 \\
1949\end{array}$} & \multirow{18}{*}{$\begin{array}{r}12,110 \\
12,740 \\
22,120 \\
11,740 \\
9,994 \\
23,480 \\
21,810 \\
12,750 \\
15,340 \\
12,290 \\
10,050 \\
20,840 \\
16,310 \\
23,930 \\
15,390 \\
20,040 \\
18,970 \\
41,320 \\
27,960\end{array}$} & \multirow{18}{*}{$\begin{array}{r}9,665 \\
4,554 \\
9,033 \\
11,760 \\
5,721 \\
9,594 \\
6,725 \\
8,348 \\
6,698 \\
6,641 \\
9,984 \\
13,830 \\
6,318 \\
9,595 \\
11,260 \\
12,080 \\
11,120 \\
16,610 \\
11,790\end{array}$} & \multirow{18}{*}{$\begin{array}{l}21,780 \\
17,290 \\
31,150 \\
23,500 \\
15,720 \\
33,070 \\
28,540 \\
21,100 \\
22,040 \\
18,930 \\
20,030 \\
34,670 \\
22,630 \\
33,520 \\
26,650 \\
32,120 \\
30,090 \\
57,930 \\
39,750\end{array}$} & 19 & & & \\
\hline & & & & & & & \\
\hline & & & & & & & \\
\hline & & & & & & & \\
\hline & & & & & & 12, & \\
\hline & & & & & & & \\
\hline & & & & 195 & & & \\
\hline & & & & & & & \\
\hline & & & & & & & \\
\hline & & & & & & & \\
\hline & & & & & & & \\
\hline & & & & \multirow{2}{*}{\multicolumn{2}{|c|}{ Aean... 1}} & & \\
\hline & & & & & & & \\
\hline & & & & \multicolumn{4}{|l|}{ Drains } \\
\hline & & & & \multirow{2}{*}{\multicolumn{4}{|c|}{$\begin{array}{l}\text { area in } \\
\text { square }\end{array}$}} \\
\hline & & & & & & & \\
\hline & & & & \multicolumn{2}{|l|}{ miles. } & \multirow{2}{*}{10,155} & 29,780 \\
\hline & & & & & & & \\
\hline
\end{tabular}


TABLE 13.-Discharge, in cubic feet per second, fromr eaches 33 and 34 , segment 10

[Records furnished by Tallahassee Office, U.S. Geol. Survey]

\begin{tabular}{|c|c|c|c|c|c|c|c|}
\hline Water year & $\underset{\mathbf{3 3}}{\text { Reach }}$ & $\underset{34}{\text { Reach }}$ & $\underset{10}{\text { Segment }}$ & Water year & $\underset{33}{\text { Reach }}$ & $\underset{34}{\text { Ragach }}$ & $\underset{10}{\text { Segment }}$ \\
\hline 931 & \multirow{18}{*}{$\begin{array}{l}1,600 \\
1,500 \\
2,500 \\
1,800 \\
1,100 \\
2,200 \\
3,200 \\
1,400 \\
1,300 \\
2,100 \\
2,400 \\
2,000 \\
1,600 \\
1,300 \\
1,600 \\
1,500 \\
2,900 \\
3,000 \\
1,600\end{array}$} & \multirow{18}{*}{$\begin{array}{r}5,600 \\
6,400 \\
9,900 \\
13,000 \\
4,100 \\
15,000 \\
7,800 \\
2,600 \\
3,800 \\
11,000 \\
9,300 \\
8,300 \\
3,800 \\
3,300 \\
4,900 \\
8,500 \\
20,000 \\
15,000 \\
5,700\end{array}$} & \multirow{18}{*}{$\begin{array}{r}7,200 \\
7,900 \\
12,400 \\
14,800 \\
5,200 \\
17,200 \\
11,000 \\
4,000 \\
5,100 \\
13,100 \\
11,700 \\
10,300 \\
5,400 \\
4,600 \\
6,500 \\
10,000 \\
22,900 \\
18,000 \\
7,300\end{array}$} & 1950 & \multirow{11}{*}{$\begin{array}{l}1,800 \\
1,850 \\
1,670 \\
1,920 \\
2,790 \\
1,610 \\
1,190 \\
2,670 \\
1,730 \\
2,290 \\
3,700\end{array}$} & \multirow{11}{*}{$\begin{array}{r}\text { 3. } 600 \\
4,600 \\
5.700 \\
8.200 \\
13.000 \\
4,900 \\
1,800 \\
4,500 \\
9.200 \\
7,300 \\
10,000\end{array}$} & \multirow{11}{*}{$\begin{array}{r}5,400 \\
6,450 \\
7,370 \\
10,120 \\
15,790 \\
6,510 \\
2,990 \\
7,170 \\
10,930 \\
9,590 \\
13,700\end{array}$} \\
\hline & & & & 195 & & & \\
\hline 93 & & & & 1952 & & & \\
\hline 7 & & & & 1953 & & & \\
\hline 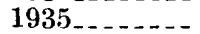 & & & & 1954 & & & \\
\hline & & & & 1955 & & & \\
\hline 93 & & & & 1956 & & & \\
\hline & & & & 195 & & & \\
\hline 1939 & & & & 195 & & & \\
\hline & & & & 195 & & & \\
\hline 1941 & & & & 1960 & & & \\
\hline & & & & \multirow[b]{2}{*}{ Mean _.. } & \multirow[b]{2}{*}{1,994} & \multirow[b]{2}{*}{7,693} & \multirow[b]{2}{*}{9,687} \\
\hline 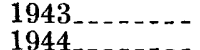 & & & & & & & \\
\hline 27 & & & & Drai & & & \\
\hline & & & & area in & & & \\
\hline 10 & & & & & & & \\
\hline & & & & miles_..... & 1,357 & 9451 & 10,808 \\
\hline & & & & & & & \\
\hline
\end{tabular}

TABLE 14.-Annual discharge of Hudson River at mouth (13,366 sq $\mathrm{mi}), 1890-1960$

[Means for the following periods: $1890-1960(71 \mathrm{yr})=21,520 \mathrm{cfs} ; 1931-60(30 \mathrm{yrs})=21,300 \mathrm{cfs}$; $1921-45(25 \mathrm{yr})=$ $20,660 \mathrm{cfs} ; 1951-60$ (10 yr) $=22,790 \mathrm{cfs}]$

\begin{tabular}{|c|c|c|c|c|c|c|c|}
\hline Water year & $\begin{array}{l}\text { Cubic feet } \\
\text { per second }\end{array}$ & Water year & $\begin{array}{l}\text { Cubic feet } \\
\text { per second }\end{array}$ & Water year & $\begin{array}{l}\text { Cubic feet } \\
\text { per second }\end{array}$ & Water year & $\begin{array}{l}\text { Cubic feet } \\
\text { per second }\end{array}$ \\
\hline 1890 & 25,970 & 1908 & 27,930 & 1926 & 22,300 & 1944 & 17,130 \\
\hline & 22,770 & 1909 & & & 18,120 & & 720 \\
\hline 1892 & 30,210 & 1910 . & 19,100 & 1928 & 28,620 & 1946 & 22,480 \\
\hline 189 & 21,570 & 1911 & 13,640 & 1929 & 21,020 & 1947 & 23,270 \\
\hline 1894 & 17,790 & 1912 & 22,500 & 1930 & 16,550 & 194 & 20,440 \\
\hline 1895 & 16,400 & 1913 & 24,200 & 1931 & 14,570 & 1949 & 18,870 \\
\hline 1896 & 21,410 & 1914 & 19,380 & 1932 & 18,020 & 1950 & 19,760 \\
\hline 1897 & 25,800 & 1915 & 17,250 & 19 & 23,650 & 1951 & 24,870 \\
\hline 1898 & 24,180 & 191 & 22,560 & 1934 & 17,960 & 195 & 29,640 \\
\hline 1899 & 20,420 & 1917 & 20,280 & 1935 & 19,900 & 195 & 23,460 \\
\hline 190 & 20,270 & 1918 & 17,830 & 1936 & 22,420 & 1954 & 19,450 \\
\hline 190 & 20,720 & 191 & 20,080 & 1937 & 23,160 & 1955 & 21,490 \\
\hline 1902 & 24,380 & 1920 & 20,510 & 1938 & 23,880 & 195 & 26,830 \\
\hline 10 & 26,810 & 1921 & 19,620 & 1939 & 21,990 & 1957 & 15,080 \\
\hline 1904 & 24,390 & 1922 & 24,290 & 1940 & 20,070 & 1958 & 21,420 \\
\hline & 24,840 & 192 & 16, & 1941 & 14,770 & 1959 & 18,450 \\
\hline 1906 & 24,440 & 1924 & 21,950 & 1942 & 16,020 & 1960 & 27,250 \\
\hline 1907 & 20,600 & 1925 & 21,580 & $1943_{--}$ & 26,840 & & \\
\hline
\end{tabular}

As explained on page I2, the Croton River basin akove Croton Dam was considered as being noncontributing, because the entire flow of the Croton River, except for spill over Croton Dam, is diverted for the New York City water supply. The spill, which is measured at a gaging station a short distance below the dam, was added to the 
flow of the Hudson River. Table 15 gives the spill from Croton Reservoir. Gaging-station records are available since 1934. During the period $1934-60$, the spill ranged from $1 \mathrm{cfs}$ in 1942 to $819 \mathrm{cfs}$ in 1956 and averaged 237 cfs for the 27 years. A flat estimate cf 235 cfs was made for the years prior to 1934 .

\section{DISCHARGE OF THE CHARLES RIVER AT MOUTH, 19?0-60}

The discharge of the Charles River at mouth was estirnated by the Boston district of the U.S. Geological Survey. Below tha gaging station at Waltham, the discharge is complicated by storm sewers, some of which carry water into the basin and some out of the basin. The discharge was estimated by calendar years to be consistent with the figures of waste from Boston sewers, the figures being furnished by the Massachusetts Metropolitan District Commission by calendar years. The waste was not added to the Charles River but was included in the discharge of Boston Bay into the ocean. Discharg? of the Charles River and the waste into Boston Harbor are shown in table 16.

TABLE 15.-Spill from Croton Reservoir

\begin{tabular}{|c|c|c|c|c|c|}
\hline Water year & $\begin{array}{l}\text { Cubic feet } \\
\text { per } \\
\text { second }\end{array}$ & Water year & $\begin{array}{c}\text { Cubic feet } \\
\text { per } \\
\text { second }\end{array}$ & Water year & $\begin{array}{l}\text { Cubic feet } \\
\text { per } \\
\text { second }\end{array}$ \\
\hline $1890-1933$ & 1235 & 1943 & 255 & $1953 \ldots$ & 452 \\
\hline 1934 & 276 & 1944 & 16 & 1954 & 2 \\
\hline 1935 & 206 & 1945 & 226 & 1955 & $28 \mathrm{c}$ \\
\hline 1936 & 210 & 1946 & 232 & 1956 & $84 \mathrm{C}$ \\
\hline 1937 & 255 & 1947 & 51 & 1957 & 184 \\
\hline 1938 & 558 & 1948 & 137 & 1958 & 341 \\
\hline 1939 & 434 & 1949 & 48 & 1959 & 223 \\
\hline 1940 & 55 & $1950 \ldots$ & 2 & 1960 & 308 \\
\hline 1941 & 34 & $1951 \ldots$ & 273 & & 80 \\
\hline $1942 \ldots \ldots$ & 1 & $1952 \ldots$ & 476 & $\begin{array}{l}\text { Mean for } \\
1934-60\end{array}$ & 237 \\
\hline
\end{tabular}

1 Estimated.

MEAN MONTHLY DISCHARGE OF PENOBSCOT AND JAMES RIVERS, 1951-60

The mean monthly discharge of the Penobscot and James Pivers at mouth for the period 1951-60 is shown in table 17. Mean monthly discharge is shown graphically in figure 3, expressed as a percentage of the mean, to give a better visual comparison of the monthly distribution of discharge of these two widely separated streams. Tre drainage area of the Penobscot River is 14 percent less than that of the James River, but mean annual discharge during the 10 -year period was 67 percent greater; in other words, the mean discharge per square mile of the Penobscot River was nearly double that of tho James River. (See also table 18.) 
TABLE 16.-Annual discharge, in cubic feet per second, of the Charles River at mouth (275 sq mi) and sewage waste into Boston Harbor, 1920-60

\begin{tabular}{|c|c|c|c|c|c|c|c|}
\hline Calendar year & $\begin{array}{l}\text { Charles } \\
\text { River }\end{array}$ & Waste & Total & Calendar year & $\begin{array}{c}\text { Charles } \\
\text { River }\end{array}$ & Waste & Total \\
\hline 1920 . & 440 & 340 & 780 & 1941. & 140 & 410 & 550 \\
\hline 1921 & 314 & 328 & 642 & 1942 & 215 & 419 & 634 \\
\hline 1922 & 357 & 319 & 676 & 1943 & 226 & 498 & 724 \\
\hline 1923. & 404 & 323 & 727 & 1944 & 191 & 455 & 646 \\
\hline 1924 & 315 & 316 & 631 & 1945 & 307 & 554 & 861 \\
\hline 1925 & 302 & 337 & 639 & 1946 & 278 & 525 & 803 \\
\hline 1926 & 288 & 343 & 631 & 1947. & 215 & 460 & 675 \\
\hline 1927 & 496 & 370 & 866 & 1948 & 286 & 511 & 797 \\
\hline 1928 & 400 & 347 & 747 & 1949 & 163 & 415 & 578 \\
\hline 1929 & 337 & 350 & 687 & 1950 & 179 & 456 & 635 \\
\hline 1930 . & 190 & 336 & 526 & 1951 . & 314 & 478 & 792 \\
\hline 1931 & 330 & 370 & 700 & 1952 & 273 & 495 & 768 \\
\hline 1932 & 231 & 351 & 582 & 1953 & 334 & 529 & 863 \\
\hline 1933 & 314 & $37 \overline{8}$ & 692 & 1954 & 391 & 562 & 953 \\
\hline 1934 & 267 & 367 & 634 & 1955 & 497 & 579 & 1,076 \\
\hline 1935 & 281 & 379 & 660 & 1956 & 392 & 605 & 997 \\
\hline 1936_ & 332 & 416 & 748 & 1957. & 182 & 518 & 700 \\
\hline 1937 & 292 & 398 & 690 & 1958 & 390 & 549 & 939 \\
\hline 1938 & 422 & 439 & 861 & 1959 & 355 & 518 & 873 \\
\hline 1939 & 249 & 398 & 647 & 1960 & 479 & 534 & 1,013 \\
\hline \multirow{2}{*}{$1940 \ldots$} & 245 & 401 & 646 & for $1931-60$ & 292 & 466 & 758 \\
\hline & & & & & & & \\
\hline
\end{tabular}

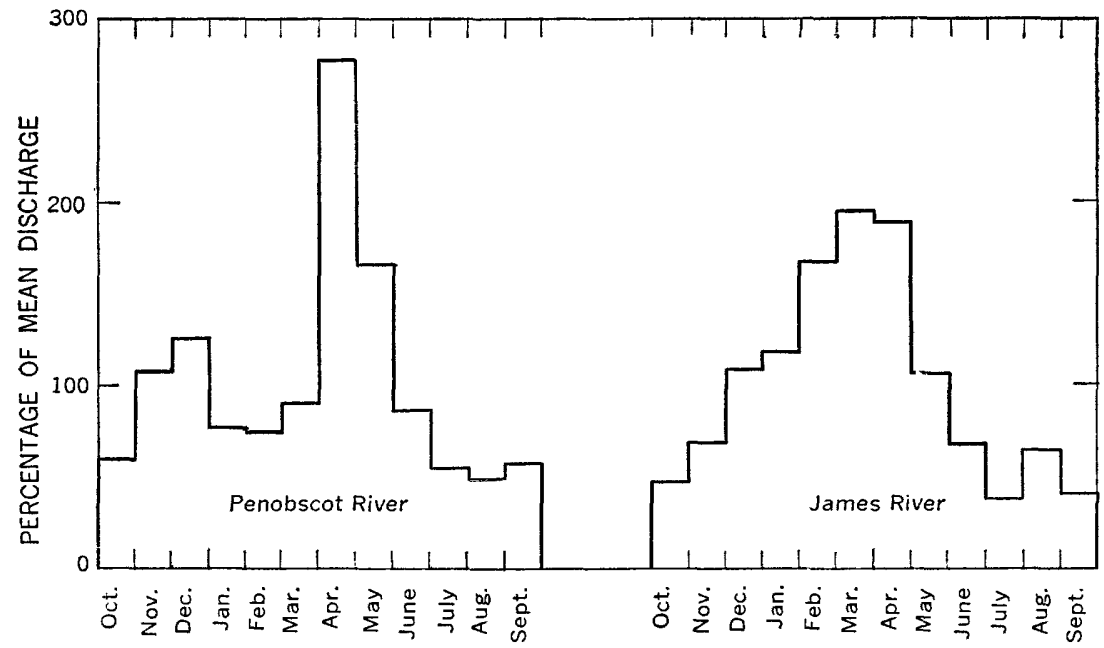

Figure 3.-Mean monthly discharge of Penobscot and James Rivers, 1951-60.

\section{DISCHARGE OF PRINCIPAL RIVERS, 1951-60 AND 1931-60}

Table 18 gives the average discharge at mouth of 33 selected rivers for the periods 1951-60 and 1931-60. The table also gives the drainage area of each and the discharge expressed in cubic feet per second per square mile. With the exception of the Schuylkill River, which is tributary to the Delaware, these rivers empty directly into the Atlantic Ocean, or into a sound or a bay. The list includes most of the coastal 
streams that have drainage areas greater than 1,000 squere miles. Stream names are in the order from north to south, going counterclockwise around Chesapeake Bay. The State names show" are the States through or between which the rivers flow at their mouths, regardless of how much of their drainage basins may be in another State.

TABLE 17.-Mean monthly discharge, in cubic feet per second, of the Penobscot and James Rivers, $1951-60$

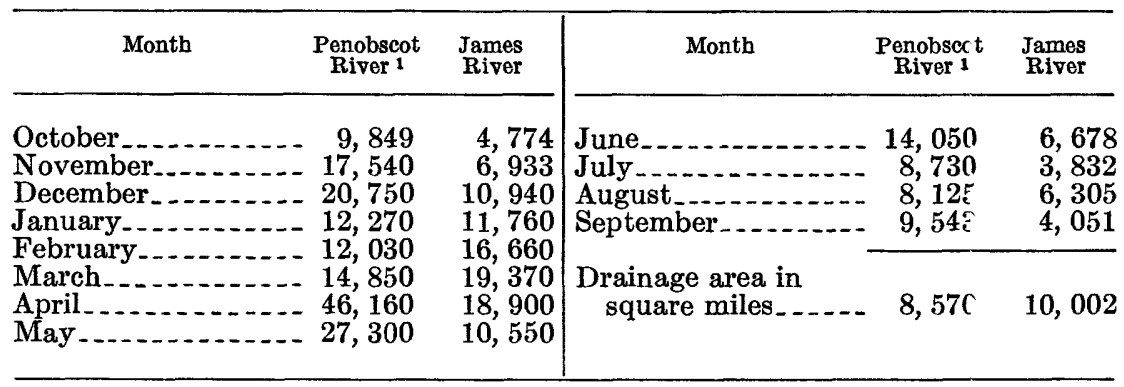

1 Does not include two areas of about 223 and 254 square miles that contribute to the north and south shores of Penobscot Bay.

TABLE 18.-Discharge of principal rivers, 1951-60 and 1981-60

\begin{tabular}{|c|c|c|c|}
\hline \multirow[t]{2}{*}{ River } & \multirow{2}{*}{$\begin{array}{c}\text { Drainage } \\
\text { area } \\
\text { (sq mi) }\end{array}$} & Mean discharge (cfs) & $\begin{array}{l}\text { Cuhic feet per } \\
\text { siscond per } \\
\text { scuare mile }\end{array}$ \\
\hline & & $1951-60$ & 10 уеаг \\
\hline
\end{tabular}

Part 1-A

St. Croix, Maine and New

Brunswick

Penobscot, Maine

Kennebec, Maine

Androscoggin, Maine

Saco, Maine

Merrimack, Massachusetts.....

Thames, Connecticut ..........

Connecticut, Connecticut........

Housatonic, Connecticut.......

1,635

8,570

5,970

3,470

1,730

14,800

1,473

11,250

1, 949

3,325
16,750
11,220
7,229
4,040
28,901
2,976
21,070

2,840

14,970

9,871

6,440

3,545

27,962

2,645

19,320

3,799
2. 03

1. 95

1. 88

2. 08

2. 34

1. 85

2. 02

1. 87

1. 95
1. 74

1. 75

1. 65

1. 85

2. 05

1. 66

1. 80

1. 72

1. 76

\section{Part 1-B}

Hudson, New York and New Jersey__._.

Raritan, New Jersey_....... 1, 105

Schuylkill, Pennsylvania....... 1,916

Delaware, Delaware and New

Jersey _........................

Susquehanna, Maryland.......

Potomac, Maryland and

Rappahannock, Virginia.......

York, Virginia_....

\section{1,415}

27,469

13,670

2,718

\section{2,790}

1,625

${ }^{6} 3,145$

719,750

840,290

${ }^{9} 14,040$

2,475

${ }^{4} 21,300$

1,580

${ }^{6} 2,960$

51.73

1. 47

1. 64

51.62

1. 43

1. 54

${ }^{7} 18,870$

1. 73

1. 65

${ }^{8} 38,100$

1. 47

1. 39

914,000

2,705

1. 03

1. 02

.91

.91

1. 00 
TABLE 18.-Discharge of principal rivers, 1951-60 and 1931-60-Continued

\begin{tabular}{|c|c|c|c|c|c|}
\hline \multirow[t]{2}{*}{ River } & \multirow{2}{*}{$\begin{array}{c}\text { Draingge } \\
\text { area } \\
\text { (sq mi) }\end{array}$} & \multicolumn{2}{|c|}{ Mean discharge (cfs) } & \multicolumn{2}{|c|}{$\begin{array}{l}\text { Cubic feet per } \\
\text { second per } \\
\text { square mile }\end{array}$} \\
\hline & & $1951-60$ & $1931-60$ & 10 year & 30 year \\
\hline \multicolumn{6}{|c|}{ Part 2-A } \\
\hline James, Virginia_. & 10,002 & ${ }^{10} 10,030$ & ${ }^{10} 10,690$ & 1. 00 & 1. 07 \\
\hline Chowan, North Carolina. & 4,929 & 4,626 & $-0=-$ & .94 & -1 \\
\hline Roanoke, North Carolina & 9,666 & 8,620 & 9,585 & .89 & 99 \\
\hline Pamlico, North Carolina & 4, 302 & $\begin{array}{l}4,693 \\
5\end{array}$ & 903 & 1. 09 & 10 \\
\hline $\begin{array}{l}\text { Neuse, North Carolina } \\
\text { Cape Fear, North Carolina. }\end{array}$ & $\begin{array}{l}5,598 \\
9,136\end{array}$ & $\begin{array}{l}5,703 \\
9,475\end{array}$ & 6,903 & $\begin{array}{l}1.02 \\
1.04\end{array}$ & .06 \\
\hline Waccamaw, South Carolina. & 1,580 & 1,522 & $=$ & .96 & $\ldots$ \\
\hline Pee Dee, South Carolina & 16,310 & 15,270 & 15,830 & .94 & .97 \\
\hline Santee, South Carolina_ & 15,700 & ${ }^{11} 15,400$ & ${ }^{11} 17,300$ & .98 & 1. 10 \\
\hline Edisto, South $\mathrm{Ca}$ & 3,045 & 2,430 & $\ldots$ & .80 & $\cdots-1$ \\
\hline $\begin{array}{l}\text { Savannah, South } \\
\text { Georgia }\end{array}$ & & 10,280 & 12,030 & 97 & 13 \\
\hline & s & 20,200 & 12,000 & & \\
\hline
\end{tabular}

\section{Part 2-B}

Ogeechee, Georgia

Altamaha, Georgia........... 14, 200

Satilla, Georgia _............. 3,440

St. Marys, Georgia and

Florida_.

St. Johns, Florida
1,480

8,740
3,513

12,140

2,146

3,878

13,140

2,460

0. 76

.85

.62

0. 84

.93

.72

1, 064

1,253

.72

1. 01

1 Excludes 210 square miles set aside for municipal use by city of Boston. (See p. I33.)

2 Adjusted for wastage; represents runoff from net area of 4,800 square miles. (See p. 133.)

3 Includes 378 square miles in Croton River basin.

1 Includes spill from Croton Reservoir. (See table i5.)

- Based on net drainage area of 12,988 square miles, and excluding spill from Croton Reservoir.

- Adjusted for diversion made by city of Philadelphia.

7 Does not include diversion from Chesapeake Bay to Delaware River through Chesapeake and Delaware Canal, estimated at 1,000 cfs for period 1951-60 and $840 \mathrm{cfs}$ for period 1931-60.

8 Not adjusted for small diversions to Baltimore and Chester (which in 1967 averaged $73 \mathrm{cfs}$ ).

9 Adjusted for diversions made above gaging station near District of Columbia and wasted back into river below station.

10 Includes flow of James River and Kanawha Canal.

11 Completely regulated; reconstructed record including diversion to Cooper River basin.

\section{COMPARISON BETWEEN DIFFERENT PERIOD"}

Mean discharges for 1951-60, 1931-60, and period of record through 1966 is shown in table 19 for gaging stations on 26 principal rivers along the coast. The gaging stations are either the farthest c'ownstream on the rivers or the stations with the longest record if the most downstream records were less than 30 years in length.

As the purpose of this study was to calculate actual streamflow into the Atlantic Ocean, the figures of mean discharge shown for 1931-60 and 1951-60 in table 19 are the observed discharge unless otherwise indicated, with the exception of the Schuylkill and Potomac Rivers, which were adjusted for water diverted above the gaging station and wasted back into the river below the gaging station. In the column showing mean discharge during the period of record, severcl means are 
qualified as being adjusted for storage or for diversions or both. These adjustments may be fairly large in some years, but over the period of record, the net effect is relatively small. Adjustments for storage may be either plus or minus in successive years, although if storage began during the period of record, the net adjustment to the period mean will always be plus. Adjustments for diversions are, of course, always in the same direction at any one gaging station.

In the Androscoggin River basin, a group of reservoirs upstream from the Auburn gaging station have a combined capacity of about 700,000 acre-feet (30.3 billion cubic feet). During the 38 -yes r period of record 1929-66, the yearly adjustments ranged from minu 402 cfs to plus $460 \mathrm{cfs}$. However, the adjustment to the mean for the period of record was only minus $2 \mathrm{cfs}$; the adjustment applicable to the 10year mean is plus $2 \mathrm{cfs}$; and no adjustment is applicable to the 30 -year mean. At the end of the 1966 water year, the amount of water in storage was about 443,500 acre-feet. Had storage begun during the rariod of record at Auburn, the adjustment applicable to the 38-year mern would have been plus $16 \mathrm{cfs}$.

In the Roanoke River basin, facilities for a large amount of storage have been constructed since 1950, and in some years since then the adjustments applicable to the observed yearly mean have bean large. In 1953, for example, $1,110 \mathrm{cfs}$ was stored. However, the ad ustment applicable to the observed mean for 1951-60 is only plus $215 \mathrm{cfs}$, and to the observed mean for 1931-60, only plus $71 \mathrm{cfs}$. The adjusted mean for the 54-year period of record 1913-66 includes an adjustment of only $47 \mathrm{cfs}$.

It is evident from the records on the Androscoggin and Roanoke Rivers that long-term means at gaging stations are little aff 3 cted by storage unless storage begins during the period of record at th? gaging station. If a large amount of water is stored during the periol of record, a short-term mean can, of course, be affected considerabl\%.

The means shown for the Savannah River at Augusta are all observed. There is considerable regulation by four reservoirs upstream from Augusta, and in the 1966 water year the monthly adjustment applicable ranged from minus $1,628 \mathrm{cfs}$ to plus $3,765 \mathrm{cfs}$, but the net adjustment applicable to the yearly mean for 1966 was only pl'ts $1 \mathrm{cfs}$.

In the published records of discharge for Merrimack Rivor below Concord River, at Lowell, Mass., the average discharge shown for the period of record has been adjusted for wastage into the Merrimack River. The figures of daily discharge are the observed discharge; the monthly summaries show both the observed monthly means and the monthly means adjusted for wastage. The term "wastage" as used here bears explanation. A tributary area of 210 square miles in the 
I 34 CONTRIBUTIONS TO THE HYDROLOGY OF THE UNIT'D STATES

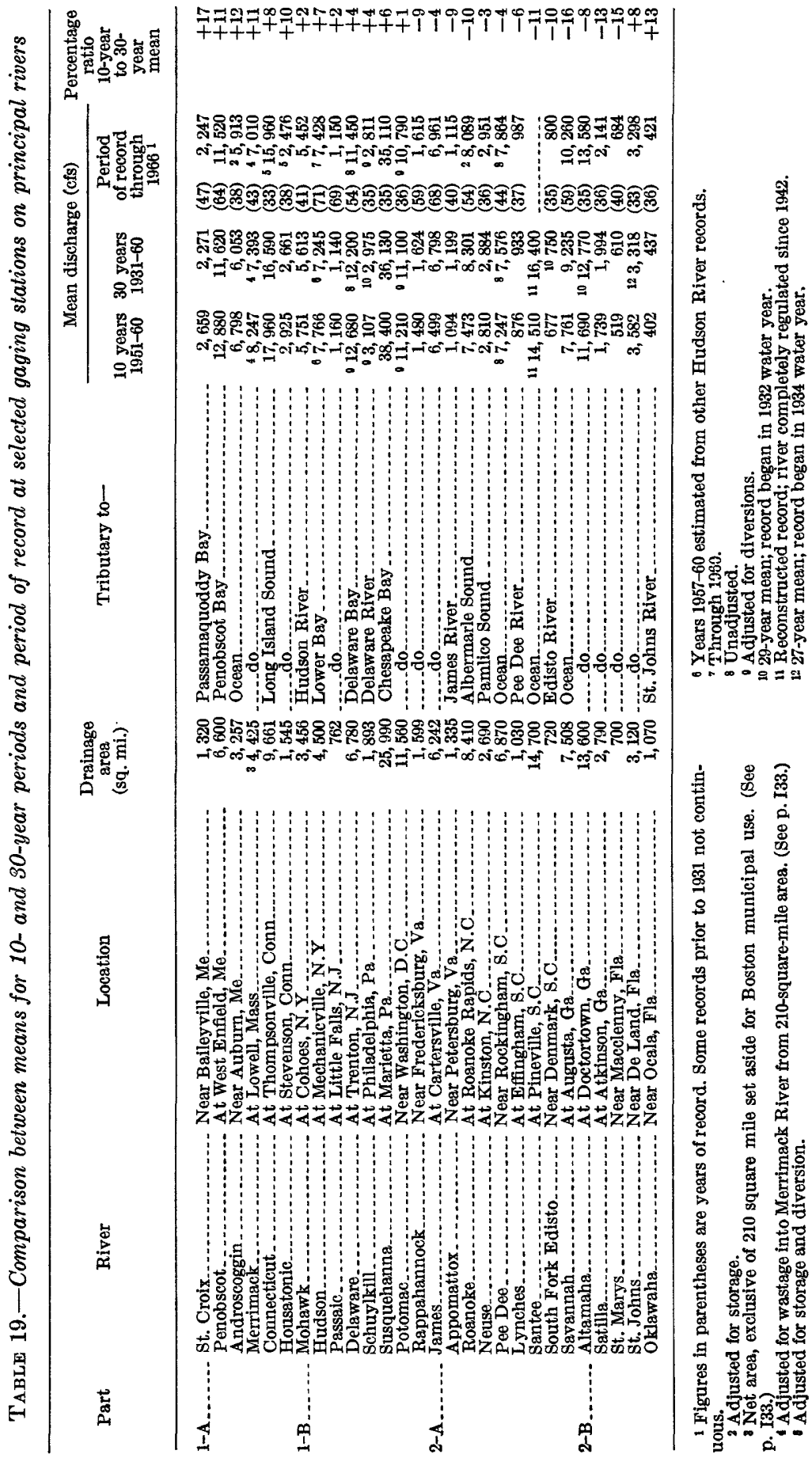


basins of the Sudbury and South Branch Nashua Rivers and Lake Cohituate has been set aside for the municipal water supply of Boston, and theoretically only the flow from the remaining 4,425 square miles passes the Lowell gaging station. Not all the flow from the 210 square miles is diverted, however, and the remainder, termed "wastage," flows into the Merrimack River and passes the Lowell gaging station. In tables 18 and 19, the figures of drainage area shown are exclisive of the 210 square miles, and the figures of mean discharge have been adjusted for wastage, because in both these tables the purpose is to show the runoff of the Merrimack River from the net drainage area. (In table 5, however, the drainage area shown for reach 8 includes the 210 square miles, and the observed discharge of the Merrimack River was used; the water diverted from the 210 square miles to the city of Boston reappears as waste in Massachusetts Bay and is included in the outflow from reach 9. See also table 16 for waste from the city of Boston.)

Table 19 shows that mean discharge was greater during 1951-60 than during 1931-60 north of the Potomac River and less south of it; on the Potomac River itself there was very little difference betreen the two periods. Exceptions are the St. Johns River and its tributary, the Oklawaha River, in northern Florida where discharge was greater during 1951-60 than during 1931-60. Total streamflow to the ocean (table 3) followed a similar pattern. In segments 1-4, the discharge to the ocean was 10 percent greater during 1951-60 than durirg 193160 ; in segment 5, which includes Delaware Bay and Chesapeake Bay, discharge was 3 percent greater during 1951-60 than during 1931-60; in segments $6-10$, discharge was 7 percent less during 1951-60 than during 1931-60; and total inflow to the ocean was 2 percent greater during 1951-60 than during 1931-60. This increase reflects the slight upward trend referred to in the section "Summary of streamflow into the Atlantic Ocean" and shown graphically in figure 2.

\section{REFERENCES}

Brice, H. D., 1951, A progress report on streamflow investigations ir Suffolk County, Long Island, 1903, 1942-47 : U.S. Geol. Survey open-flle report, 114 p.

Carter, R. F., 1959, Drainage area data for Georgia streams : U.S. Geo'. Survey open-flle report, $252 \mathrm{p}$.

Durfor, C. N., and Becker, Edith, 1964, Public water supplies of the 1C0 largest cities in the United States, 1962: U.S. Geol. Survey Water-Supply Paper $1812,364 \mathrm{p}$.

Hidore, John, 1966, Regional variation in natural water consumpticn in the conterminous United States: Jour. Hydrology, v. 4, p. 79-90.

Langbein, W. B., and others, 1949, Annual runoff in the United States: U.S. Geol. Survey Circ. 52, 14 p.

Maine State Water Storage Commission, 1910, First Annual Report: Augusta, Kennebec Journal Print. 373 p. [1911]. 
1913, Fourth Annual Report: Waterville, Sentinel Publishirg Co., 323 p. [1914].

Manheim, F. T., 1967, Evidence for submarine discharge of water or the Atlantic Continental Slope of the southern United States, and suggestiors for further search: New York Acad. Sci. Trans., ser. 2, v. 29, p. 839-853.

New York Department of Water Supply, Gas and Electricity, 1952, A description of the water-supply system of the city of New York : $63 \mathrm{p}$.

Sawyer, R. M., 1959, Progress report on streamflow investigations in Nassau County, Long Island, 1903, 1937-55 : U.S. Geol. Survey open-file report, 225 p.

U.S. Department of the Army, Corps of Engineers, 1965, Inland waterway between Delaware River and Chesapeake Bay-Problem of disposal of material to be removed from a portion of channel in the Chesapeake Fay : Committee on Tidal Hydraulies, $10 \mathrm{p}$.

- 1967, Inland waterway, Delaware River to Chesapeake Fay-Historic Chesapeake and Delaware Canal: Philadelphia District, pamplet.

U.S. Weather Bureau, 1955, Mean annual total precipitation, based on years 1931-55 : Rainfall map.

1959, Evaporation maps for the United States: U.S. Weather Bur. Tech. Paper 37, 13 p., 5 pl.

Vermeule, C. C., 1894, Water supply : Trenton, Geol. Surrey of Ner Jersey, vol. 3 , Final report of the State Geologist, $352 \mathrm{p}$.

Virginia Department of Conservation and Economic Development, 1960, Index of the surface waters of Virginia, $66 \mathrm{p}$.

Walker, P. N., 1962, Drainage areas at selected sites on streams in North Carolina [revised in 1965] : U.S. Geol. Survey open-file report, $80 \mathrm{p}$

Water Resources Council, 1968, The Nations water resources: Washington, D.C., The First National Assessment of the Water Resources Council, pt. 3, chap. 2, p. 6. 